\title{
Sekizinci Sınıf Öğrencilerinin Yenilenebilir Enerji Kaynaklarına İlişkin Algılarının Bilim Karikatürleri Aracılığıyla İncelenmesi*
}

\section{Investigation of Eighth Grade Students' Renewable Energy Resources Perceptions by Science Cartoons}

\author{
Tuba YILDIRIM** iD \\ Nagihan TANIK-ÖNAL \\ Uğur BÜYÜK ${ }^{* * *}$ (DD \\ Received: 04 April 2018 \\ Research Article \\ Accepted: 03 January 2019
}

ABSTRACT: In this study, which aims to reveal the perceptions of eighth grade students about renewable energy sources by science cartoons, phenomenology is used. Participants are 20 students totally, who are studying in a secondary school in Kayseri in the second semester of the academic year of 2014-2015, determined by criterion sampling, and 12 female and 8 male at the eighth grade level. Process of the study lasted 4 weeks. Science cartoons drawn by the students and semi-structured interviews were used as data collection tools in the study. The data were analyzed by content analysis. As a result of the research it was seen that the participants could not define the energy and make sufficient explanations about the energy conversion and some students had incorrect information. In addition, the research data also show that the examples given by the participants on renewable energy sources and non-renewable energy sources are correct and inadequate. This situation can be achieved with trainings which will increase the level of awareness of the students about energy problems, renewable energy sources, non-renewable energy sources and energy saving. Also, it seems essential to make the concepts concrete and associate them with daily life and to realize permanent learning.

Keywords: science cartoons, phenomenology, renewable energy resources, students' perceptions.

ÖZ: Sekizinci sınıf öğrencilerinin yenilenebilir enerji kaynaklarına ilişkin algılarını bilim karikatürleri aracılığıyla ortaya koymayı amaçlayan bu çalışmada nitel araştırma yönteminden olgu bilim (fenomenoloji) deseni kullanılmıştır. Çalışmanın katılımcıları 2014-2015 eğitim-öğretim yılı ikinci yarıyılında Kayseri’de bir ortaokulda öğrenim görmekte olan, ölçüt örnekleme ile belirlenen ve sekizinci sınıf düzeyinde 12'si kız 8'i erkek toplam 20 öğrencidir. Çalışma 4 hafta sürmüştür. Çalışmada veri toplama aracı olarak öğrenciler tarafindan çizilen bilim karikatürleri ve araştırmacının öğrencilerle gerçekleştirdiği yarı yapılandırılmış görüşmelerden yararlanılmış, dokümanlardan elde edilen veriler içerik analizi ile çözümlenirken yarı yapılandırılmış görüşmelerin analizi betimsel analiz ile gerçekleştirilmiştir. Araştırma sonucunda katılımcıların enerjiyi tanımlayamadıkları, enerji dönüşümüne ilişkin yeterli açıklamalar yapamadıkları ve bazı ögrencilerin doğru olmayan bilgilere sahip oldukları görülmüştür. Ayrıca araştırma verileri, katılımcılar tarafından yenilenebilir enerji kaynakları ve yenilenemez enerji kaynaklarına ilişkin verilen örneklerin doğru olmakla beraber yetersiz olduğunu da göstermektedir. Bu durumun öğrencilerin enerji sorunları, yenilenebilir enerji kaynakları, yenilenemez enerji kaynakları ve enerji tasarrufu konularında farkındalık düzeylerini artıracak, kavramları somutlaştırıp günlük hayatla ilişkilendirerek kalıcı öğrenmeler gerçekleştirecek bir eğitimle giderilebileceği düşünülmektedir.

Anahtar kelimeler: bilim karikatürleri, fenomenoloji, yenilenebilir enerji kaynakları, öğrenci algıları.

\footnotetext{
"This paper was presented as an oral presentation at " $3^{\text {rd }}$ International Eurasian Educational Research Congress" organized by Muğla Sitkı Koçman University between 31 May-3 August 2016 in Turkey.

${ }^{* *}$ Ph.D. Student, Erciyes University, Kayseri, Turkey, tubayldrm38@gmail.com

**** Asst. Prof. Dr., Erciyes University, Kayseri, Turkey, ntanik@erciyes.edu.tr

***** Corresponding Author: Prof. Dr., Erciyes University, Kayseri, Turkey, buyuk@erciyes.edu.tr
}

\section{Citation Information}

Yıldırım, T., Tanık-Önal, N., \& Büyük, U. (2019). Sekizinci sınıf öğrencilerinin yenilenebilir enerji kaynaklarına ilişkin algılarının bilim karikatürleri aracılığıyla incelenmesi. Kuramsal Ĕgitimbilim Dergisi [Journal of Theoretical Educational Science], 12(1), 342-368. 


\section{Giriş}

Çevre, insanların ve yeryüzünde bulunan bütün canlıların karşılıklı olarak etkileşim içinde bulunduğu ortam olarak tanımlanabilir (Seçgin, Yalvaç, \& Çetin, 2010). Dolayısıyla canlılar için çevre oldukça önemli olmasına karşın günümüzde çevre sorunları hızla artan dünya nüfusu, plansız sanayileşme ve sağlıksız kentleşme, nükleer denemeler, bölgesel savaşlar, verimi artırmak amacıyla kullanılan tarım ilaçları, yapay gübreler ve deterjan vb. kimyasal maddelerin kullanımı gibi faktörler sebebiyle tüm dünyada giderek artmaktadır (Güney, 2004).

Tüm dünyada olduğu gibi ülkemizde de çevre sorunları hızla artmaktadır. OECD (Organisation for Economic Co-operation and Development) çevre raporuna göre bu sorunların başında bilinçsiz enerji tüketimi gelmektedir (OECD, 2008). Petrolün keşfedilmesi sonrası kömür ve petrol dünyanın her yerinde enerji kaynağı olarak kullanılmaya başlanmış ve bu yaygın kullanım geri dönüşümü zor çevre kirliliğine sebep olmuştur. Ayrıca halen enerji üretmek amacıyla kullanılan kömür ve petrol gibi yer altı kaynaklarının yakın zamanda tükeneceği düşünülmektedir. Bu kaynakların yenilenemez olması, bilim adamlarını dünya için yeni enerji kaynakları araştırmaya sevk etmiştir. $\mathrm{Bu}$ araştırmalar sonucunda fosil yakıtlara alternatif olarak yenilenebilir enerji kaynaklarının kullanımı uygun görülmüştür. Güneş, rüzgâr, dalga, hidrojen, hidroelektrik, biyokütle, jeotermal enerji gibi kaynaklar yenilenebilir enerji kaynaklarıdır ve bu kaynaklar çevre kirliliğine çok az neden olmaktadır (World Wide Fund for Nature [WWF], 2011).

$\mathrm{Bu}$ nedenle bireylerin yenilenebilir enerji kaynaklarını kullanması ve yenilenebilir enerji kaynaklarının özendirilmesi çevre için önemlidir. Bu bağlamda çevre sorunları ve bu sorunlara yönelik çözüm arayışları pek çok eğitim araştırmasına da konu olmuştur. Alanyazına bakıldığında ilköğretim programlarının çevre eğitimi açısından incelenmesi (Akınoğlu \& Sarı, 2009; Aydın \& Ürey, 2014; Tanrıverdi, 2009), çevre sorunlarına dair öğretmen adaylarının (Aksan \& Çeliker, 2013) ve ilköğretim öğrencilerinin düşüncelerinin araştırılmasına ilişkin çalışmalara (Ersoy \& Türkkan, 2010; Seçgin, Yalvaç, \& Çetin, 2010) sıklıkla rastlanmış olmasına rağmen çevre bilincinin temel öğelerinden biri olan enerji sorunları ve yenilenebilir enerjiye ilişkin ortaokul öğrencilerinin algılarının araştırıldığı çalışmalara sınırlı sayıda rastlanmıştır (Kılıçaslan, Peker, \& Gün, 2011). Oysa çevre bilincinin oluşturulmasında büyük öneme sahip olan enerji sorunları ve yenilenebilir enerji kaynakları konusunda ortaokul öğrencilerinin sahip oldukları algılar, onların çevreye yönelik tutumlarını, çevre bilinçlerini ve duyarlılıklarını etkileyebilme noktasında oldukça önemlidir.

Bireylerin bir konu ile ilgili algılarını ortaya koymak için en iyi araçlardan biri karikatürlerdir (Keogh \& Naylor, 1999). Karikatür türlerinden biri olan ve bu araştırmada kullanılan bilim karikatürleri (science cartoons) ise alan yazında "scientoon" olarak yer almaktadır. Bilim karikatürleri öznesi bilim olan karikatürler olarak tanımlanmıştır (Srivastava, 2011). Bilim karikatürlerinin etkili iletişimi sağlama, karmaşık bilimsel ifadelerin anlaşılmasını kolaylaştırma gibi avantajlarının yanında görsel olması sebebiyle evrensel bir dil niteliği taşıdığı da bilinmektedir (Srivastava, 2011). Görsel açıdan güçlü bir araç olan karikatürdeki mizah ile insanlar, olayların, durumların ya da kişilerin eleştirisini komiklik unsurunu da içerecek biçimde ele almalarıyla birlikte duygu ve düşüncelerini ifade etme imkânı da bulurlar (Ersoy \& Türkkan, 2010). 
$\mathrm{Bu}$ çalışmada; öğrencilerin, çizdikleri bilim karikatürleri sayesinde enerji sorunları ve yenilenebilir enerji kaynakları konularındaki algılarının açığa çıkarılması amaçlanmıştır. Araştırma sorusu "Sekizinci sınıf öğrencilerinin yenilenebilir enerji kaynaklarına ilişkin algıları nasıldır?" olan bu araştırmada, öğrencilerin algıları aşağıda sunulan her bir alt problem için cinsiyet açısından incelenmiştir.

1. Sekizinci sınıf öğrencilerinin yenilenebilir enerji kaynaklarına ilişkin algıları nasildir?

2. Sekizinci sınıf öğrencilerinin yenilenebilir enerji kaynaklarının kullanımının çevreye etkilerine ilişkin algıları nasıldır?

3. Sekizinci sınıf öğrencilerinin yenilenemez enerji kaynaklarına ilişkin algıları nasildır?

4. Sekizinci sınıf öğrencilerinin yenilenemez enerji kaynaklarının kullanımının çevreye etkilerine ilişkin algıları nasıldır?

5. Sekizinci sınıf öğrencilerinin enerji tasarrufuna ilişkin algıları nasıldır?

6. Sekizinci sınıf öğrencilerinin enerji dönüşümüne ilişkin algıları nasıldır?

Yöntem

\section{Araştırmanın Modeli}

Sekizinci sınıf öğrencilerinin enerji sorunları ve yenilenebilir enerji kaynaklarına ilişkin algılarını bilim karikatürleri aracılığıyla ortaya koymayı amaçlayan bu çalışmada nitel araştırma yönteminden olgu bilim (fenomenoloji) deseni kullanılmıştır. Bu desende gerçekleştirilen çalışmalar; deneyimler, algılar, yönelimler ve kavramlar gibi olguları daha iyi anlamamıza yardımcı olacak örnekler, açıklamalar ve yaşantılar ortaya koyabilirler (Creswell, 2008). Bir başka ifade ile olgu bilim; bir olgu ile ilgili bireylerin yaşadıkları deneyimleri betimledikleri ve bu betimlemeler sonucunda katılımcıların deneyimlerinin özüne ulaşılan bir desendir (Van Manen, 1990). Bu araştırmada da katılımcılar yenilenebilir enerji kaynakları hakkında bilgi ve belli bir tecrübeye sahip oldukları için olgu bilim deseni seçilmiştir.

\section{Çalışma Grubu}

Araştırmanın çalışma grubu 2014-2015 eğitim-öğretim y1lı ikinci yarıyılında Kayseri'de bir ortaokulda sekizinci sınıfta öğrenim görmekte olan 20 öğrenci olarak belirlenmiştir. Öğrencilerden 12'si kız; 8'i erkektir. Çalışma grubunun belirlenmesinde nitel araştırmalarda örneklem belirleme geleneklerinde yer alan amaçlı örneklem yöntemlerinden ölçüt örnekleme kullanılmıştır. Ölçüt örnekleme yöntemindeki temel anlayış, önceden belirlenmiş bir dizi ölçütü karşılayan bütün durumların çalışılmasıdır (Yıldırım \& Şimşek, 2011). Bu araştırma kapsamında belirlenen ölçüt ise; çalışma grubunda yer alacak ögrencilerin sekizinci sınıf fen bilimleri eğitim programında yer alan enerji sorunları ve yenilenebilir enerji kaynakları konusunda eğitim görmüş olmalarıdır. $\mathrm{Bu}$ sayede katılımcıların fenomenolojiye uygun bir şekilde araştırma konusu ile ilgili bir deneyime sahip olmaları dikkate alınmıştır. Çalışma kapsamında yer alan yarı yapılandırılmış görüşmelerin katılımcıları da bu 20 öğrenci içerisinden gönüllülük ilkesi esasına dayalı olarak belirlenmiş 4'ü kız 3'ü erkek olmak üzere toplam 7 öğrenciden oluşmaktadır. 


\section{Veri Toplama Araçları}

Çalışmada veri toplama aracı olarak, öğrenciler tarafından çizilen bilim karikatürlerini içeren dokümanlar ve araştırmacının öğrencilerle gerçekleştirdiği yarı yapılandırılmış görüşme formları kullanılmıştır.

\section{Bilim Karikatürleri}

Dokümanlar, nitel araştırmalarda etkili bir şekilde kullanılması gereken önemli bilgi kaynaklarıdır (Yıldırım \& Şimşek 2011). Bu araştırmanın dokümanlarını, öğrenciler tarafından çizilen bilim karikatürleri oluşturmaktadır. Bu karikatürlerin hangi konularda olacağı öğrencilerin enerji sorunları ve yenilenebilir enerji kaynaklarına ilişkin edinmiş olmaları muhtemel kazanımlar göz önünde bulundurularak oluşturulmuştur. Bu dokümanların analizi sonucunda öğrencilerin enerji sorunları ve yenilenebilir enerji kaynaklarına ilişkin algılarının açığa çıkarılması hedeflenmiştir.

\section{Yarı Yapılandırılmış Görüşmeler}

Araştırmada kullanılan bir diğer veri toplama aracı ise yarı yapılandırılmış görüşmelerdir. $\mathrm{Bu}$ türden bir görüşmede daha çok araştırmacının belirlediği ve öğrenmek istediği sorulara cevap aranır. Görüşmeler öncesinde araştırmacı görüşmede hangi konuya odaklanacağını ve hangi sorulara cevap arayacağını belirler (Öztürk, 2014). Görüşme formunda yer alan maddeler araştırmacılar tarafindan literatürden faydalanılarak öğrencilerin enerji sorunları ve yenilenebilir enerji kaynaklarına ilişkin edinmiş olmaları muhtemel kazanımlar arasından seçilerek oluşturulmuştur. Ayrıca görüşme formunun oluşturulması aşamasında formda yer alacak olan madde içeriklerinin, öğrencilerin çizmiş oldukları bilim karikatürleri içerikleriyle paralellik göstermesi gerekliliği de göz önünde bulundurulmuştur.

\section{Verilerin Toplanması}

Pilot Uygulamalar. Araştırmada veri toplama aşamasına geçmeden önce pilot uygulamalar yapılmıştır ve bu süreç şu şekilde gerçekleşmiştir. Öncelikle öğrencilere bilim karikatürleri ile ilgili bilgiler verilmiş, örnek bilim karikatürleri sunularak ilgili karikatürler üzerinde tartışmaları sağlanmıştır. Tartışmalar sonucu, bilim karikatürlerinin ne anlattığı öğrencilerin de yorumları alınarak araştırmacı tarafından açıklanmıştır. Sonrasında ön uygulama olarak öğrencilerden örnek bilim karikatürleri çizmeleri istenmiştir. Yapılan çizimler incelendiğinde bilim karikatürünün öğrenciler tarafından anlaş1ldığ 1 görülmüştür.

Çalışma kapsamında oluşturulan görüşme formunun işlerliği ve amaca uygunluğu noktasında da bir dizi çalışmalar gerçekleştirilmiştir. Yarı yapılandırılmış görüşme formu araştırmacı tarafından oluşturulduktan sonra formun araştırma amacına uygunluğu ve kapsam geçerliğinin kontrolü amacıyla fen eğitimi alanında uzman olan üç kişiye, dilsel açıdan anlaşılabilirliğinin kontrolü amacıyla ise Türkçe eğitimi alanında uzman bir kişiye inceletilmiştir. Uzman görüşleri doğrultusunda revize edilen form ile 8. sınıf seviyesinde bulunan üç öğrenci ile pilot uygulamalar gerçekleştirilmiştir. Pilot uygulamalar ile formun iyi çalışıp çalışmadığı, maddelerin öğrenciler tarafından anlaşı1ıp anlaşılmadığı ortaya konmuş ve araştırmacı esas uygulamalar öncesinde bir deneyim kazanmıştır. Pilot uygulamalar sonrasında görüşme formunda bazı değişiklikler yapılmıştır. Örneğin, öğrencilerin ilk aşamada enerji, enerji sorunları, 
enerji dönüşümü, enerji tasarrufu nedir sorularına yeterli cevaplar veremedikleri görülmüştür. $\mathrm{Bu}$ sonuç göz önüne alınarak düzenlenen görüşme formunda sorulara ilişkin; "enerji dönüşümü nasıl yapılır", "enerji tasarrufu gerekli midir”, "enerji tasarrufu gerekli ise enerjiden nasıl tasarruf edilir" gibi sorular eklenmiştir. Öğrencilere yenilenebilir enerji kaynaklarının neler olduğu sorulduğunda güneş, rüzgâr gibi enerji kaynaklarını örnek gösterdikleri görülmüştür. Bu durum üzerine bu kaynakların neden yenilenebilir oldukları sorusu yöneltilerek öğrencilerin cevaplarını detaylandırmaları, güneş, rüzgâr gibi yenilenebilir enerji kaynaklarının uzun ömürlü olmalarına ilişkin farkındalıkları belirlenmeye çalışılmıştır. Aynı işlem yenilenemez enerji kaynakları nelerdir sorusu için de uygulanmıştır. Öğrencilere yenilenebilir enerji kaynaklarının kullanımının çevreye etkileri nelerdir sorusu yöneltilmiştir. Bu sorulara verilen cevaplar incelendikten sonra öğrencilerin bu etkileri nasıl yorumladıklarını görmek, yenilenebilir enerji kaynaklarının kullanımına ilişkin algılarını daha detaylı belirlemek amacıyla yenilenebilir enerji kaynakları çevreyi nasıl etkiler bu etkiler size göre olumlu mu olumsuz mu gibi sorular yöneltilmiştir. Aynı işlem yenilenemez enerji kaynaklarının kullanımının çevreye etkilerine ilişkin algıları belirlemek amacıyla oluşturulan görüşme sorusunun revize edilmesi aşamasında da uygulanmıştır. Tüm bu işlemler ile forma son hali verilmiş ve uygunluğu noktasında uzmanlardan olumlu dönüt alınmıştır. Formda yer alan maddelerden biri örnek olarak verilmiştir.

1. Yenilenebilir enerji kaynakları hakkında ne düşünüyorsunuz?

Sizce bu kaynaklar neler olabilir?

$>\mathrm{Bu}$ bahsettiğiniz kaynakların hangi yönüyle yenilenebilir olduğunu düşünüyorsunuz?

Pilot uygulamalarının tamamlanmasının ardından araştırmanın verilerinin toplanması süreci başlamış ve bu süreç toplamda dört hafta sürmüştür. Öğrencilerin yenilenebilir ve yenilenemez enerji kaynaklarına ilişkin algılarını belirlemek amacıyla, öğrencilerden her bir alt probleme yönelik bilim karikatürü çizmeleri istenmiştir. Çizimler araştırmacının gözetiminde öğrenciler tarafından bireysel olarak gerçekleştirilmiştir. Pilot uygulamalar sırasında öğrencilerin bir ders saatinde iki konu ile ilgili çizim yapabildikleri gözlenmiştir. Bu doğrultuda asıl uygulamalarda altı konu ile ilgili her hafta bir ders saati olmak üzere toplam üç hafta bilim karikatürleri çizdirilerek veriler toplanmıştır. Süreçte, ilk hafta katılımcıların yenilenebilir enerji kaynakları, yenilenebilir enerji kaynakları kullanımının çevreye etkisi ve enerji tasarrufu konularında bilim karikatürleri çizmeleri istenmiştir. İkinci ve üçüncü haftalar da ise sırasıyla yenilenemez enerji kaynakları, yenilenemez enerji kaynakları kullanımının çevreye etkileri ve enerji dönüşümü konularında çizimler yaptırılmıştır. Dördüncü hafta ise katılımcılarla yarı yapılandırılmış görüşmeler gerçekleştirilmiştir.

Çizimler tamamlandıktan sonra bir diğer veri toplama tekniği olan mülakatlar gerçekleştirilmiştir. Mülakatlar 4'ü kız 3’ü erkek olmak üzere toplam 7 öğrenci ile ses kaydı alarak gerçekleştirilmiş olup her bir öğrenci için ortalama 20-25 dk. sürmüş ve transkriptleri yapılmıştır. 


\section{Verilerin Analizi}

Doküman Analizi. Bu kapsamda öncelikle öğrencilerin çizmiş oldukları bilim karikatürleri tek tek incelenmiş, kontroller sonucunda 20 öğrencinin çizimleri kızlar için; K1, K2... ve erkekler için; E1, E2... şeklinde kodlanmıştır. Katılımcıların oluşturduğu bilim karikatürlerinin analizinde içerik analizi yöntemi kullanılmıştır. İçerik analizinde temel amaç toplanan verileri açıklayabilecek kavramlara ve ilişkilere ulaşmaktır (Yıldırım \& Şimşek, 2011). İçerik analizinde toplanan veriler önce kavramsallaştırılır daha sonra ortaya çıkan kavramlar göz önünde bulundurularak temalar oluşturulur ve bu sayede mantıklı bir çerçeve çizilmeye çalışılır (Yıldırım \& Şimşek, 2011). Bu analiz yönteminde verilerden çıkarılan kavramlara göre kodlamalar yapılır. Kodlama; veri parçaları (metin, cümle, paragraf) sorgulanarak içinde bulundurduğu anlamın ortaya çıkarılmaya çalışılması şeklindedir (Berg, 2001).

Literatürde, daha önce öğrencilerin enerji sorunları ve yenilenebilir enerji kaynaklarına ilişkin algılarının bilim karikatürleri aracılığıyla incelendiği çalışmaya rastlanamamış olması ve bu konudaki çizimlerin değerlendirilmesi noktasında kullanılacak değerlendirme ölçütünün bulunmaması sebebiyle kodlamalar araştırmacı tarafından doğrudan verilerden üretilmiştir ve aynı işlemler üç alan uzmanı tarafından da gerçekleştirilmiş olup ortaya çıkan kodlar üzerinde \%90 görüş birliğine varılmıştır.

Görüşmelerin Analizi. Verileri çeşitlemek ve öğrencilerin bu konudaki algılarını açığa çıkarmak için bilim karikatürlerine ek olarak öğrencilerle yapılmış olan görüşmelerden yararlanılmıştır. Katılımcıların izni ile ses kayıt cihazı kullanılarak kaydedilen görüşmeler ilk önce harfiyen yazılıp yazılı doküman haline getirilmiştir. Görüşmelerin tamamının transkripsiyonu yaklaşık iki haftalık bir süre içerisinde gerçekleştirilmiştir. Elde edilen görüşme metinleri MS Word programında birleştirildiğinde 11,150 sözcükten oluşan 62 sayfalık bir veri metni elde edilmiştir. Sonrasında ise betimsel analiz gerçekleştirilmiştir.

Geçerlik ve Güvenirlik. Bilimsel araştırmaların sonuçlarının inandırıcılığını sağlamak için, geçerlik ve güvenirlik açılarından kabul edilebilir olması gerekir (Yıldırım \& Şimşek 2011). Bu araştırmada geçerlik ve güvenirliği sağlamak amacıyla şu çalışmalar yapılmıştır: Katılımcıların kimlikleri gizli tutularak onlara kodlar verilmiş ve bu kodlar kullanılarak alıntılar sunulmuştur. Böylece çalışmanın aktarılabilirliği sağlanmıştır. Veri toplama aracının çalışma grubuna uygunluğu, bulguların ayrıntılı betimlenmesi gibi özellikler açısından üç farklı uzmana inceletilerek çalışmanın iç geçerliği (inandırıcılığı) sağlanmıştır. Verilerin analizi kısmında ise bilim karikatürleri üç araştırmacı tarafından ayrı ayrı incelendikten sonra araştırmacılar bir araya gelerek kodlar üzerinde fikir birliğine varmış böylece çalışmanın iç güvenirliğinin (tutarlılığının) artırılması sağlanmıştır. Bilim karikatürlerinden elde edilen bulguların öğrencilerle gerçekleştirilen görüşmelerden elde edilen bulgularla tutarlılık gösterdiği gözlenmiştir. Farklı yöntemlerle elde edilen bulguların birbirleriyle anlamlı bir bütün oluşturması sayesinde çalışmanın iç geçerliği sağlanmıştır. Ayrıca, öğrencilerin çizdikleri bilim karikatürlerinden ve onlarla gerçekleştirilen görüşmelerden elde edilen verilere açıklık getirmek, geçerlik ve güvenirliği artırmak amacıyla alıntılara yer verilmiştir. Araştırmanın dış güvenirliğini (teyit edilebilirliğini) artırmak amacıyla da 
bir fen eğitimcisi bu çalışmanın ham verilerini, yöntemini ve bulgularını tutarlık bakımından incelemiştir.

\section{Bulgular}

Sekizinci sınıf öğrencilerinin enerji sorunları ve yenilenebilir enerji kaynaklarına ilişkin algılarının incelendiği çalışmanın bu bölümünde, öğrenciler tarafından çizilen bilim karikatürleri ve öğrencilerle gerçekleştirilen görüşmelerden elde edilen bulgulara yer verilmiştir.

\section{Bilim Karikatürlerinden Elde Edilen Bulgular}

Öğrencilerin enerji tasarrufu, enerji dönüşümü, yenilenebilir ve yenilenemez enerji kaynakları ile bu kaynakların kullanımının çevreye etkilerine ilişkin olmak üzere toplamda altı konu hakkında çizmiş oldukları toplam 120 bilim karikatüründen elde edilen bulgular her başlık altında kız ve erkek öğrenciler açısından ayrı ayrı irdelenmiştir. Çizimlerden elde edilen kodlara açıklık getirmek, aynı zamanda araştırmanın geçerlik ve güvenirliğini artırmak amacıyla çizimlerden bazılarına yer verilmiştir.

\section{Yenilenebilir Enerji Kaynaklarına İlişkin Öğrenci Algıları}

Katılımcıların yenilenebilir enerji kaynaklarına ilişkin algılarını belirlemek amacıyla yenilenebilir enerji kaynaklarına ilişkin bir bilim karikatürü çizmeleri istenmiştir. Öğrencilerin çizmiş oldukları bilim karikatürleri araştırmacı tarafindan incelenerek kodlanmıştır. "Yenilenebilir enerji" teması adı altında oluşturulan bu kodlar Tablo 1'de sunulmuştur.

Tablo 1

Yenilenebilir Enerji Kaynaklarına İlişkin Öğrenci Algıları

\begin{tabular}{lll}
\hline Kod & K1zlar & Erkekler \\
\hline Güneş & $\mathrm{K} 2, \mathrm{~K} 3, \mathrm{~K} 4, \mathrm{~K} 5, \mathrm{~K} 8, \mathrm{~K} 9, \mathrm{~K} 12$ & $\mathrm{E} 1, \mathrm{E} 2, \mathrm{E} 4$ \\
Rüzgâr & $\mathrm{K} 6, \mathrm{~K} 7, \mathrm{~K} 11$ & $\mathrm{E} 3, \mathrm{E} 5, \mathrm{E} 6, \mathrm{E} 7$ \\
Güneş ve Rüzgâr & $\mathrm{K} 1, \mathrm{~K} 10$ & - \\
$\mathrm{Su}$ & - & $\mathrm{E} 8$ \\
\hline
\end{tabular}

Tablo 1'de de görüldüğü üzere elde edilen bulgular öğrencilerin büyük çoğunluğunun yenilenebilir enerji kaynaklarını güneş ve rüzgâr olduğunu düşündüklerini göstermektedir. 12 k1z öğrenciden 7'si (K2, K3, K4, K5, K8, K9, K12) ve 8 erkek öğrenciden 3 'ü (E1, E2, E4) çizimlerinde güneşe yer verirken 3 k1z (K6, K7, K11) ve 4 erkek öğrenci (E3, E5, E6, E7) rüzgâr örneğini kullanmışlardır. Kızlarda K1 ve K10 rüzgâr ve güneş örneğini birlikte kullanırken erkek öğrencilerden E8'in diğer öğrencilerden farklı olarak çiziminde su örneğini kullandığı görülmüştür.

$\mathrm{Bu}$ katılımcılardan algılarını net olarak ortaya koyduğu düşünülen K3 ve E5 kodlu öğrencilerin çizimleri Şekil 1'de sunulmuştur. 
Şekil 1. K3 ve E5 Kodlu Öğrencilerin Çizimleri
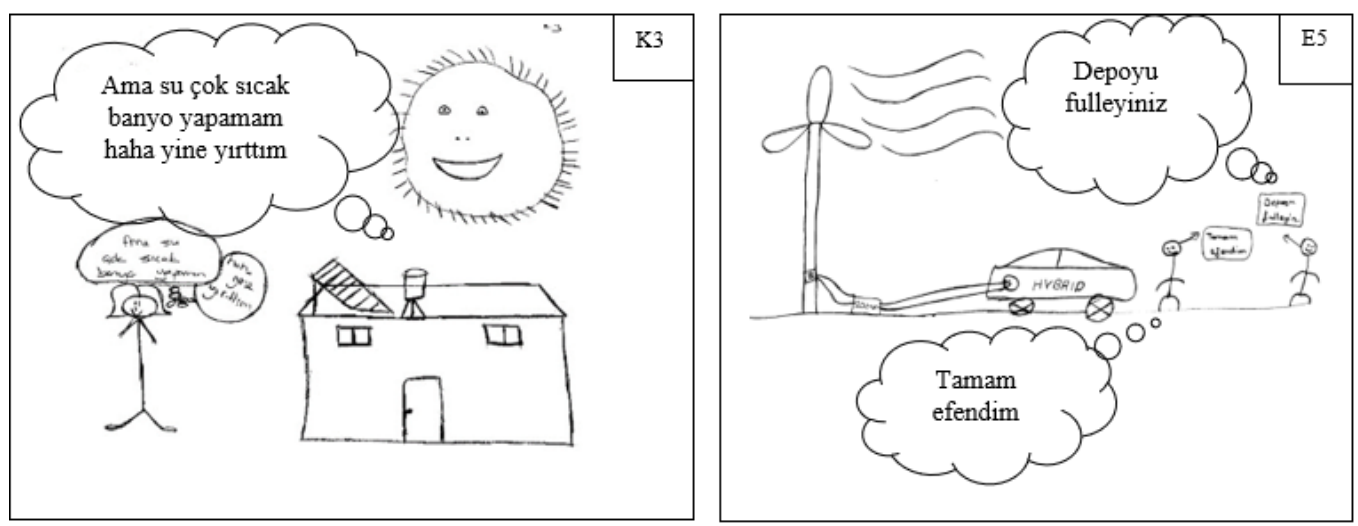

Şekil 1'de görüldüğü üzere K3 kodlu öğrenci çiziminde suları 1sıtmada kullanılan güneşi, yenilenebilir enerji kaynağına örnek göstermiştir. K3 kodlu öğrenci çiziminde evlerin çatılarında bulunan sistemler sayesinde güneşin 1sıtma özelliğinden faydalanıldığını mizahi bir dille ifade etmiştir. E5 kodlu öğrencinin çiziminde ise elektrik enerjisiyle çalışan hibrit teknolojili araba yer almaktadır. E5, çiziminde araba için gerekli olan elektrik enerjisinin yenilenebilir enerji kaynaklarından biri olan rüzgâr sayesinde yel değirmenlerinde üretildiğini ifade etmiştir.

\section{Yenilenebilir Enerji Kaynaklarının Çevreye Etkilerine İlişkin Öğrenci Algıları}

Öğrenciler, çizmiş oldukları karikatürlerde yenilenebilir enerji kaynaklarının kullanımının çevreye olumlu veya olumsuz etkileri olabileceğini belirtmişlerdir. "Yenilenebilir enerji kaynaklarının çevreye etkisi" teması adı altında oluşturulan kodlar Tablo 2'de sunulmuştur.

Tablo 2

Yenilenebilir Enerji Kaynaklarının Kullanımının Çevreye Etkilerine İlişkin Öğrenci Algilar

\begin{tabular}{llll}
\hline Çevreye Etki & Kod & Kızlar & Erkekler \\
\hline \multirow{3}{*}{ Olumlu } & Bitkilerin gelişimi & K7, K10 & E1 \\
& Temiz Çevre & K1, K4 & E2, E5, E6 \\
& Enerji Üretimi & K5, K12 & E3, E4 \\
& Is1 Kaynağ1 & K2, K8 & E7 \\
\hline \multirow{2}{*}{ Olumsuz } & Çevreye Zarar & K6 & - \\
& Zararlı Işınlar & K1 & - \\
& Atıkları Sürükleme & K3, K9 & E8
\end{tabular}

Çizimlerden elde edilen bulgulara göre 12 kız öğrenciden 8'i için (K1, K2, K4, K5, K7, K8, K10, K12), 8 erkek öğrenciden de 7'si için (E1, E2, E3, E4, E5, E6, E7) yenilenebilir enerji kaynaklarının kullanımının çevreye olumlu etkileri vardır. Kızlardan K1 ve K4, erkeklerden ise E2, E5, E6 bu etkiyi çevreyi kirletmemeleri şeklinde 
belirtmişlerdir. K7 ve E1'e göre yenilenebilir enerji kaynaklarından biri olan güneşin bitkilerin büyümesine olumlu etkisi varken, K2, K8 ve E7 ise su 1sıtmada enerji kaynağ olarak kullanılmasının olumlu etkisi olabileceğine ilişkin çizimler yapmışlardır. Bir başka bakış açısıyla kızlardan K5 ve K12 erkeklerden ise E3 ve E4 bu olumlu etkiyi yenilenebilir enerji kaynaklarının enerji üretmeleri olarak belirtmişlerdir.

$\mathrm{Bu}$ öğrencilerden K1 Şekil 2'de yer alan çiziminde yenilenebilir enerji kaynaklarından güneş ve rüzgârı birlikte kullanmıştır. Bu kaynakların kullanımının çevre kirliliğine yol açmadığını, yenilenebilir enerji kaynaklarının kullanıldığı çevrede insanların ve doğanın mutlu olduğunu resmetmiştir. E1 kodlu öğrenci ise çiziminde yenilenebilir enerji kaynaklarından biri olan güneşin bitkilerin büyümesi ve gelişmesi için gerekli olduğunu dolayısıyla yenilenebilir enerji kaynaklarının çevreye olumlu etkileri olduğunu ifade etmiştir.

Şekil 2. K1 ve E1 Kodlu Öğrencilerin Çizimleri
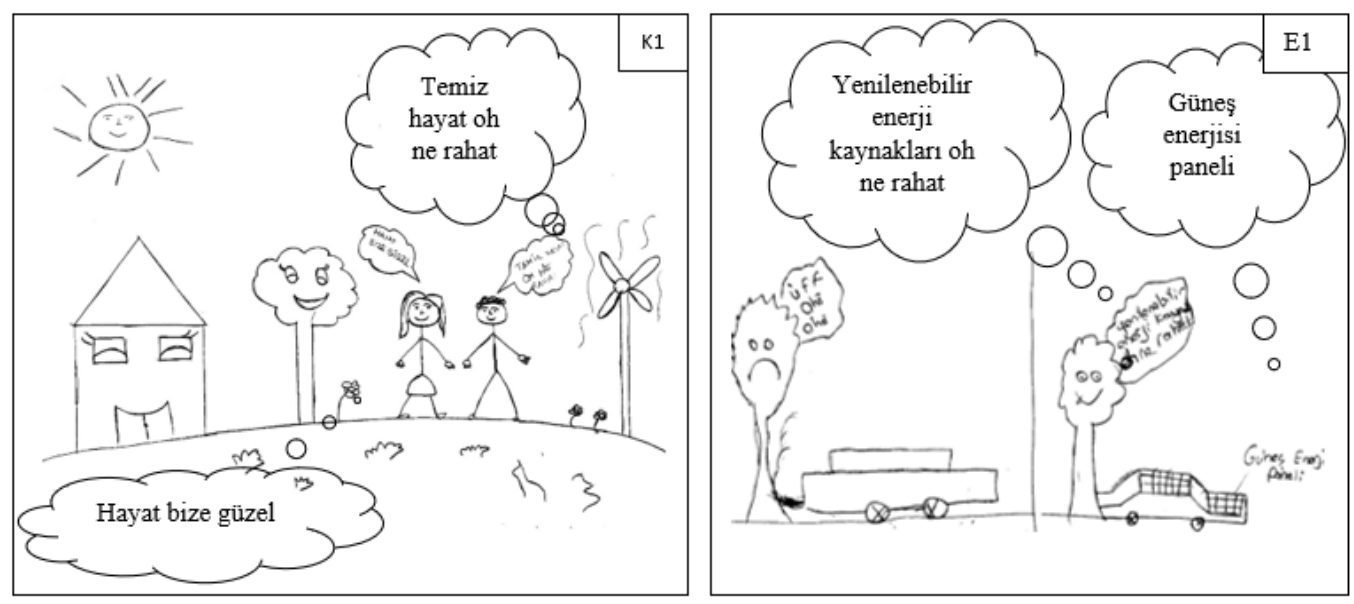

Ayrıca k1z öğrenciden K3, K6, K9, K11, erkek öğrencilerden ise E8, çizimlerinde yenilenebilir enerji kaynakları kullanımının çevreye olumsuz etkileri olabileceğini belirtmişlerdir. Kız öğrencilerden K3 ve K9; erkek öğrencilerden ise E8, bu olumsuzluğu yenilenebilir enerji kaynaklarından biri olan rüzgârın çeşitli atıkları ve çöpleri sürüklemesi sonucu çevre kirliliğine sebep olması, K6 ise rüzgârın ağaçlara zarar vermesi şeklinde yorumlamıştır.

K11 kodlu öğrenci ise Şekil 3'te yer alan çiziminde elinde bir ayna olan kişinin aynanın yansıtıcı özelliği sayesinde güneşten gelen zararlı 1şınları çöpe atacağını bu sayede yenilenebilir enerji kaynaklarından biri olan güneşin çevreye verilen olumsuz etkilerinden korunmanın mümkün olduğunu belirtmiştir. 
Şekil 3. K3 ve K11 Kodlu Öğrencilerin Çizimleri
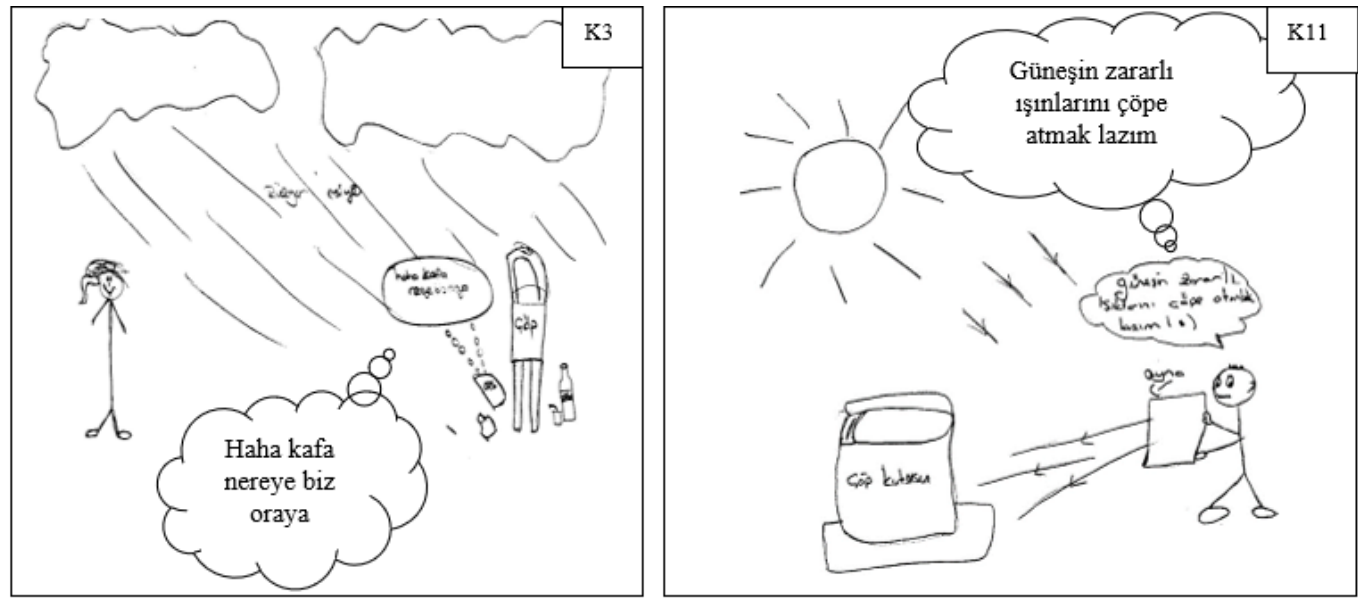

\section{Yenilenemez Enerji Kaynaklarına İlişkin Öğrenci Algıları}

Katılımcıların yenilenemez enerji kaynaklarına ilişkin çizmiş oldukları bilim karikatürlerinden elde edilen kodlar "yenilenemez enerji kaynakları" teması altında Tablo 3'te sunulmuştur.

Tablo 3

Yenilenemez Enerji Kaynaklarına İlişkin Öğrenci Algıları

\begin{tabular}{lll}
\hline Kod & Kizlar & Erkekler \\
\hline Kömür & K2, K3, K6, K10 & E1, E2, E7 \\
Petrol & K8, K11, K12 & E3, E6, E8 \\
Kömür ve Petrol & - & E4 \\
Benzin & K1, K5 & E5 \\
Doğalgaz & K4, K7 & - \\
Nükleer Santral & K9 & - \\
\hline
\end{tabular}

Bilim karikatürlerinden elde edilen bulgulara göre 12 k1z öğrenciden 4'ü (K2, $\mathrm{K} 3, \mathrm{~K} 6, \mathrm{~K} 10)$ ve 8 erkek öğrenciden 3'ü (E1, E2, E7) yenilenemez enerji kaynaklarına ilişkin çizmiş oldukları bilim karikatüründe kömürü örneğini kullanırken, kızlardan K8, K11, K12, erkeklerden ise E3, E6 ve E8 petrol örneğini kullanmışlardır. E4 kodlu öğrenci ise çiziminde hem petrole hem kömüre yer vermiştir. Kızlarda K1 ve K5, erkeklerde ise E5 çizimlerinde yenilenemez enerji kaynağı olarak benzin örneğini kullanmışlardır. K4 ve K7 çiziminde doğalgazı ele alırken K9 ise diğer arkadaşlarından farklı olarak nükleer santral örneğini kullanmıştır.

Bu öğrencilerden K6 ve K10 Şekil 4'te yer alan çizimlerinde kömürün sobada yakılmasını ele almışlardır. Çiziminde sobada yanan kömürleri konuşturan K10 "bi daha mı gelicez dünyaya" ifadesiyle kömürün yenilenemez enerji kaynağı olduğunu mizahi bir dille ifade etmiştir. 
Şekil 4. K6 ve K10 kodlu öğrencilerin çizimleri
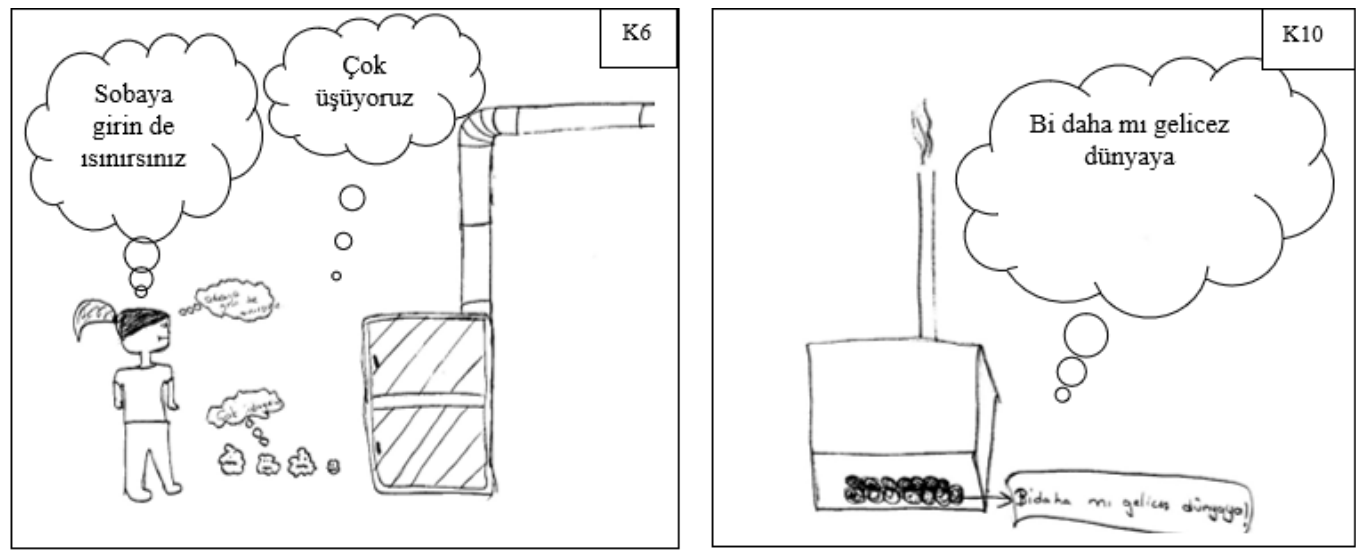

E4 kodlu öğrenci ise Şekil 5'te yer alan çiziminde yenilenemez enerji kaynağ olarak petrol ve kömürü birlikte kullanmıştır. Çiziminde yenilenebilir enerji kaynaklarından biri olan güneşin, petrol ve kömürün bir gün biteceğini ifade ettiğini dolayısıyla bu kaynakların yenilenemez olduğu gerçeğine vurgu yaptığı görülmektedir. $\mathrm{K} 1 \mathrm{z}$ öğrencilerden $\mathrm{K} 1$ ve $\mathrm{K} 5$ erkek öğrencilerden ise E5 diğerlerinden farklı olarak yenilenemez enerji kaynaklarına ilişkin çizmiş oldukları bilim karikatüründe benzine de yer vermişlerdir. Öğrencilerden K5' in çizimi Şekil 5'te sunulmuştur:

Şekil 5. E4 ve K5 Kodlu Öğrencilerin Çizimleri

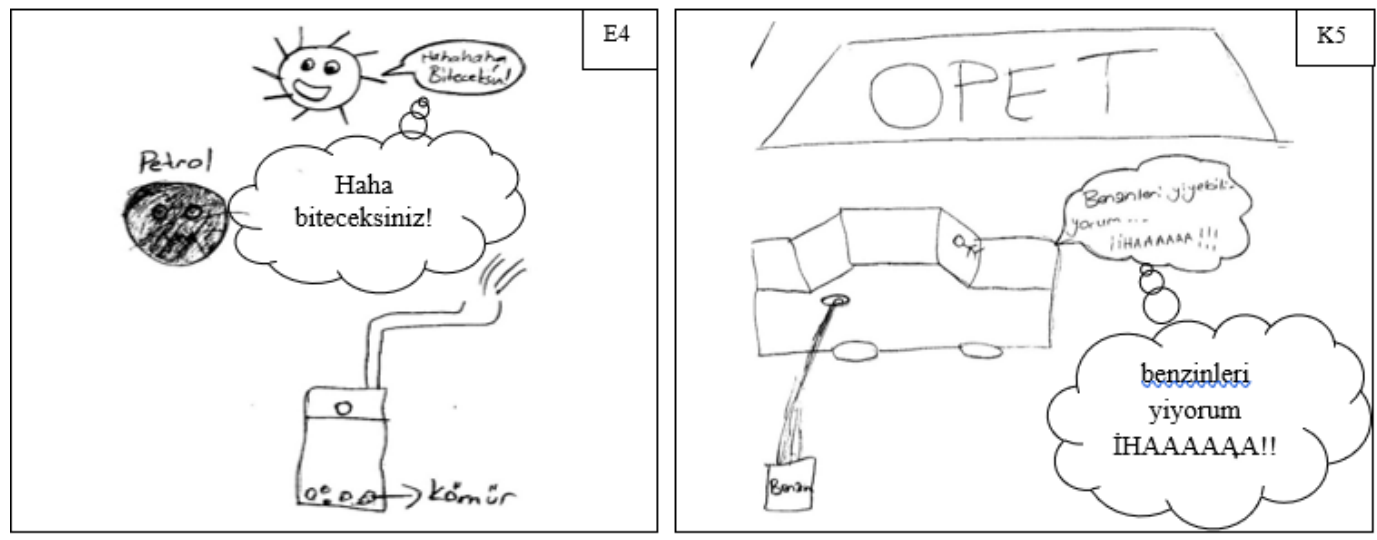




\section{Yenilenemez Enerji Kaynakları Kullanımının Çevreye Etkilerine İlişkin Öğrenci Algıları}

Katılımcıların yenilenemez enerji kaynakları kullanımının çevreye etkilerine ilişkin algılarını belirlemek amacıyla katılımcılardan bir bilim karikatürü çizmeleri istenmiştir. Çizimlerden elde edilen kodlar "yenilenemez enerji kaynaklarının çevreye etkisi" teması adı altında oluşturulan kodlar Tablo 4'te sunulmuştur.

Tablo 4

Yenilenemez Enerji Kaynaklarının Kullanımının Çevreye Etkilerine İlişkin Öğrenci Algilarl

\begin{tabular}{llll}
\hline Çevreye etki & Kod & Kizlar & Erkekler \\
\hline Olumsuz & Hava Kirliliği & K1, K3, K4, K5, K7, & E1, E2, E3, E4, E5, E6, \\
& & K9, K10 & E7, E8
\end{tabular}

Olumlu-Olumsuz

Sağlık

$\mathrm{K} 2, \mathrm{~K} 6, \mathrm{~K} 8, \mathrm{~K} 11, \mathrm{~K} 12$

Gereklilik

K5

E3

Öğrencilerin tamamı cinsiyet farkı olmaksızın çizmiş oldukları bilim karikatürlerinde yenilenemez enerji kaynaklarının kullanımının çevreyi olumsuz etkilediğini belirtmekle beraber K5 ve E3 kodlu öğrenciler bu kaynakların kullanımının gerekli olduğunu dolayısıyla yenilenemez enerji kaynaklarının olumsuz etkilerinin yanında olumlu etkilerinin de olduğunu belirtmişlerdir.

Bu etkileri 12 k1z öğrencinin 7'si (K1, K3, K4, K5, K7, K9, K10) ve 8 erkek öğrencinin tamamı hava kirliliği olarak çizimlerine yansıtmışlardır. Öğrencilerden E4 Şekil 6'da yer alan çiziminde sobada yanan kömürü yenilenemez enerji kaynağı olarak göstermiş ve kömürün kullanımının hava kirliliğine yol açtığını belirtirken, K9 kodlu öğrenci de benzer şekilde yenilenemez enerji kaynaklarından biri olan kömürün kullanımının hava kirliliğine yol açtığını Şekil 6'da yer alan çizimine yansıtmıştır.

Şekil 6. E4 ve K9 Kodlu Öğrencilerin Çizimleri
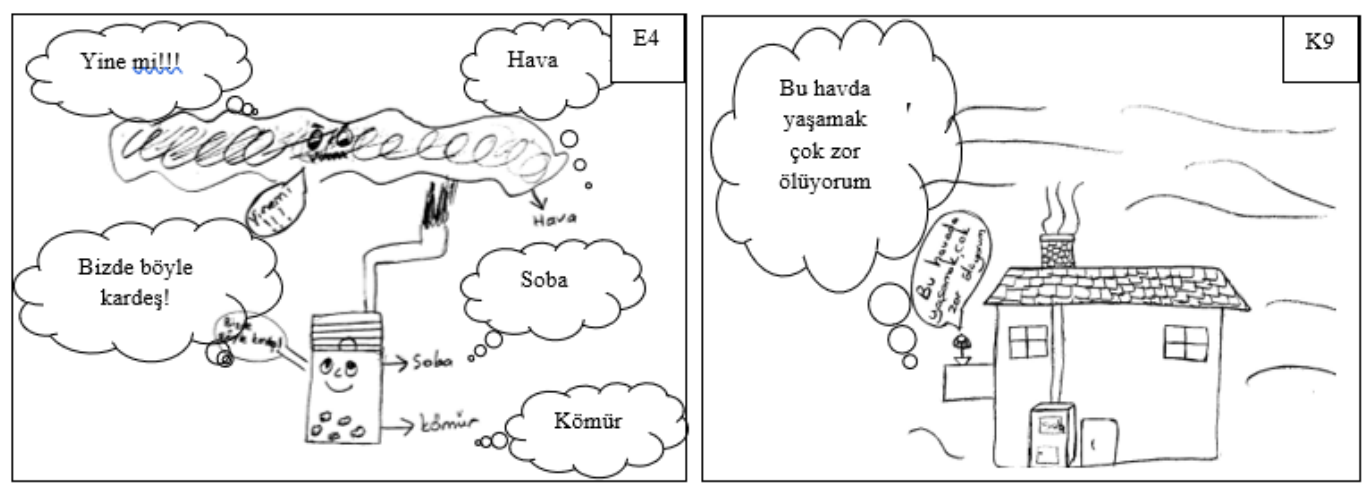

E3 ve K5 kodlu öğrenciler yenilenemez enerji kaynakları kullanımının hava kirliliğine sebep olduğunu çizimlerine yansıtmakla beraber, arabaların çalışmasının yenilenemez enerji kaynakları sayesinde olduğunu dolayısıyla yenilenemez enerji 
kaynakları kullanımının çevreye hem olumlu hem olumsuz etkisi olduğunu belirtmişlerdir.

Öte yandan k1z öğrencilerden $\mathrm{K} 2, \mathrm{~K} 6, \mathrm{~K} 8, \mathrm{~K} 11$ ve K12 yenilenemez enerji kaynaklarının insan sağlığına olumsuz etkisi olduğunu belirtmişlerdir. Bu etkileri; K2 ve K6 zehirlenme, K11 ve K12 doğalgaz patlaması olarak çizimlerine yansıtmışlardır.

K8 kodlu öğrenci ise Şekil 7'de yer alan bilim karikatüründe yenilenemez enerji kaynağı olan kömürün elde edilmesi amacıyla yapılan çalışmalar yüzünden insanların hayatlarını kaybettiğini 13 Mayıs 2014 tarihinde Manisa ili Soma ilçesinde yaşanan ve büyük sayıda can kaybıyla sonuçlanan acı bir olayı konu alarak ifade etmiştir. Bu çarpıcı örnek Şekil 7'de yer almaktadır.

Şekil 7. K12 ve K8 Kodlu Öğrencilerin Çizimleri
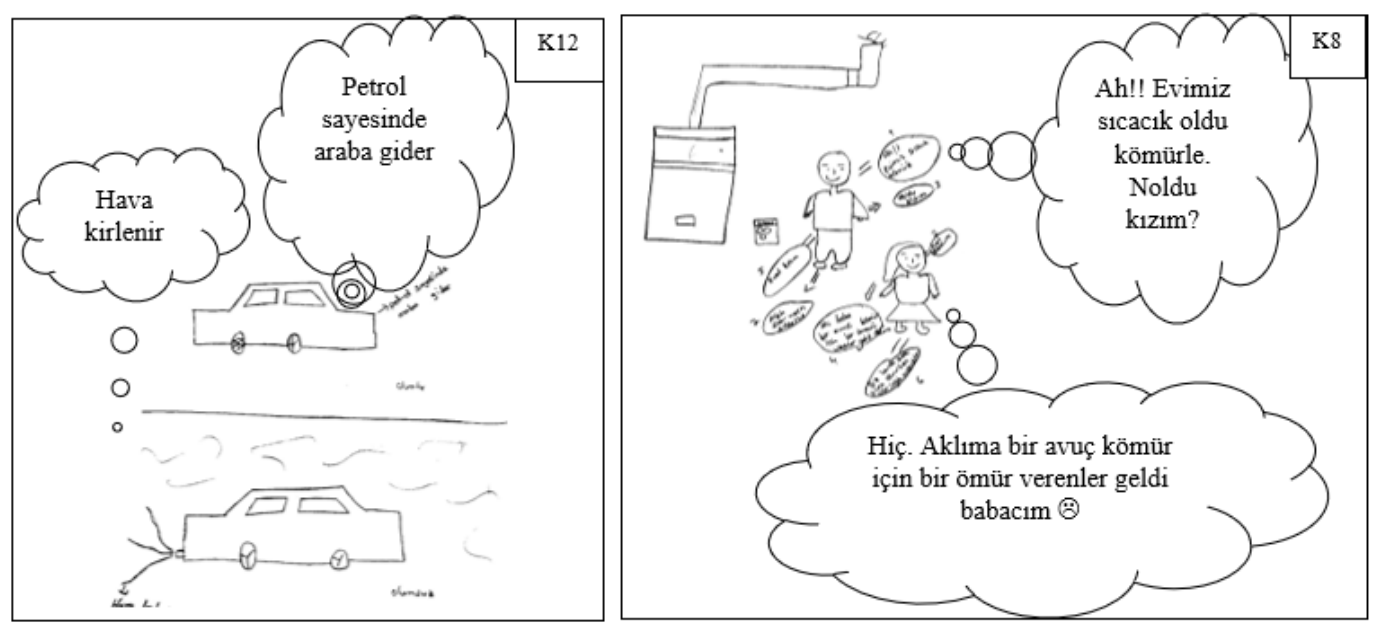

\section{Enerji Tasarrufuna İlişkin Öğrenci Algıları}

Katılımcıların enerji tasarrufuna ilişkin algılarını belirlemek adına bir bilim karikatürü çizmeleri istenmiştir. Karikatürlerden elde edilen kodlar "enerji tasarrufu" teması altında Tablo 5'te yer almaktadır.

Tablo 5

Enerji Tasarrufuna İlişkin Öğrenci Algıları

\begin{tabular}{lll}
\hline Kod & Kizlar & Erkekler \\
\hline Elektrik Tasarrufu & $\mathrm{K} 3, \mathrm{~K} 4, \mathrm{~K} 6, \mathrm{~K} 7, \mathrm{~K} 9, \mathrm{~K} 10, \mathrm{~K} 11$, & $\mathrm{E} 1, \mathrm{E} 2, \mathrm{E} 3, \mathrm{E} 7$ \\
& $\mathrm{~K} 12$ & \\
Su Tasarrufu & $\mathrm{K} 1, \mathrm{~K} 2, \mathrm{~K} 5$ & $\mathrm{E} 4, \mathrm{E} 5$ \\
Enerji Tasarrufu & - & E6 \\
\hline
\end{tabular}

Karikatürler incelendiğinde kız ve erkek öğrencilerin ilk sırada elektrik tasarrufu örneğine yer verdikleri görülmüştür. Buna göre; 12 kız öğrenciden 8'i (K3, K4, K6, K7, K9, K10, K11, K12) ve 8 erkek öğrenciden 4'ü (E1, E2, E3, E7) enerji tasarrufuna ilişkin çizmiş oldukları karikatürlerde ağırlıklı olarak elektrikli aletlerin kullanımına dikkat çekmişlerdir. K7 kodlu öğrenci Şekil 8'de yer alan çiziminde televizyon örneğini ele alarak elektrikli aletlerin kullanılmadıkları zaman tamamen kapalı olmaları 
gerektiğini, bu yolla enerji tasarrufu yapılabileceğini belirtirken, E6 kodlu öğrenci Şekil 8 'de yer alan çiziminde enerji tasarrufu konferansını konu edinmiştir. Çizimde bir konuşmacının dünya için enerji tasarrufu yapılması gerekliliğinden bahsettiğini resmeden E6 güneş ve kuşların konuşmacının fikrine katıldığını, insanlarınsa konferansta konuşan kişiyi “yuuh”layarak bu konuda ne kadar duyarsız olduklarını belirtmiştir.

Şekil 8. K7 ve E6 Kodlu Öğrencilerin Çizimleri

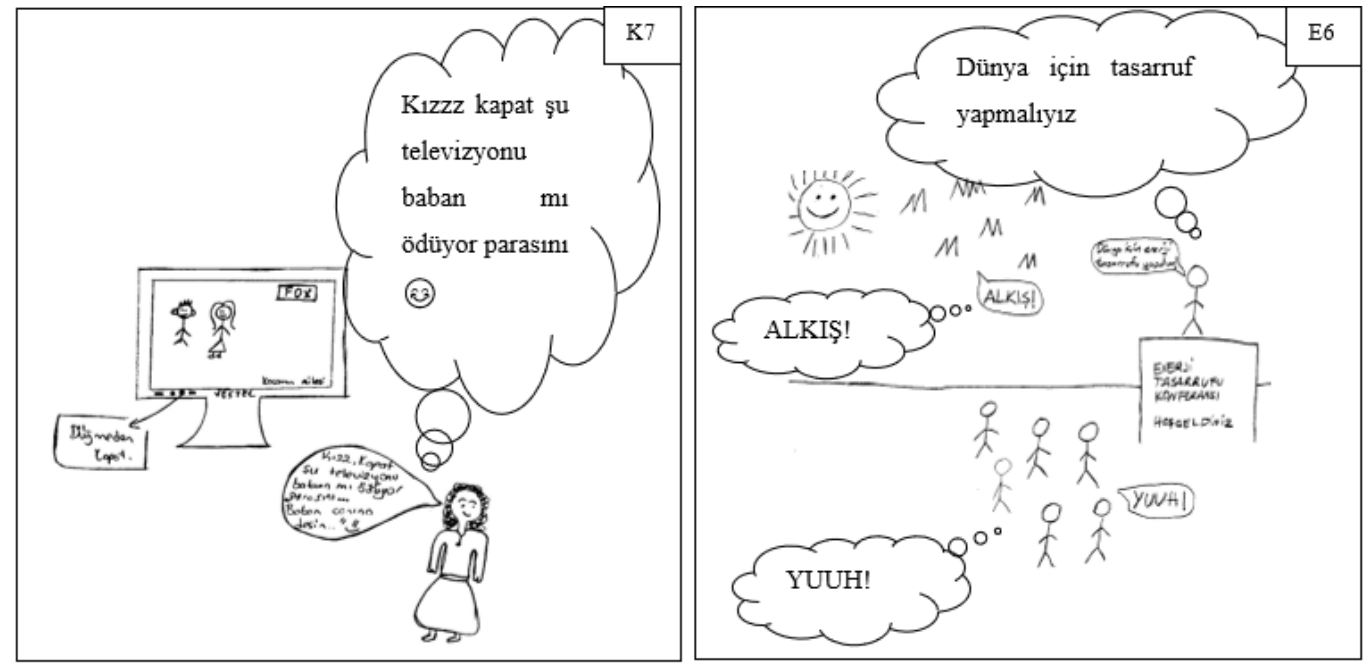

Kızların (K1, K2, K5) ve erkeklerin (E4, E5) çizimlerinde ikinci sırada su tasarrufu konusunun işlendiğini görülmüştür. Bu öğrencilerden K5 Şekil 9'da yer alan çiziminde musluğu konuşturarak muslukların açık bırakılması durumunda suların gereğinden fazla aktığını ve bu durumun önüne geçilmesi gerektiğini resmetmiştir. E5 kodlu öğrenci de çiziminde K5 kodlu arkadaşına benzer şekilde muslukların açık bırakılmaması gerektiğine dikkat çekmiştir. Öğrencilerin bu çizimleri Şekil 9'da yer almaktadır.

Şekil 9. K5 ve E5 Kodlu Öğrencilerin Çizimleri
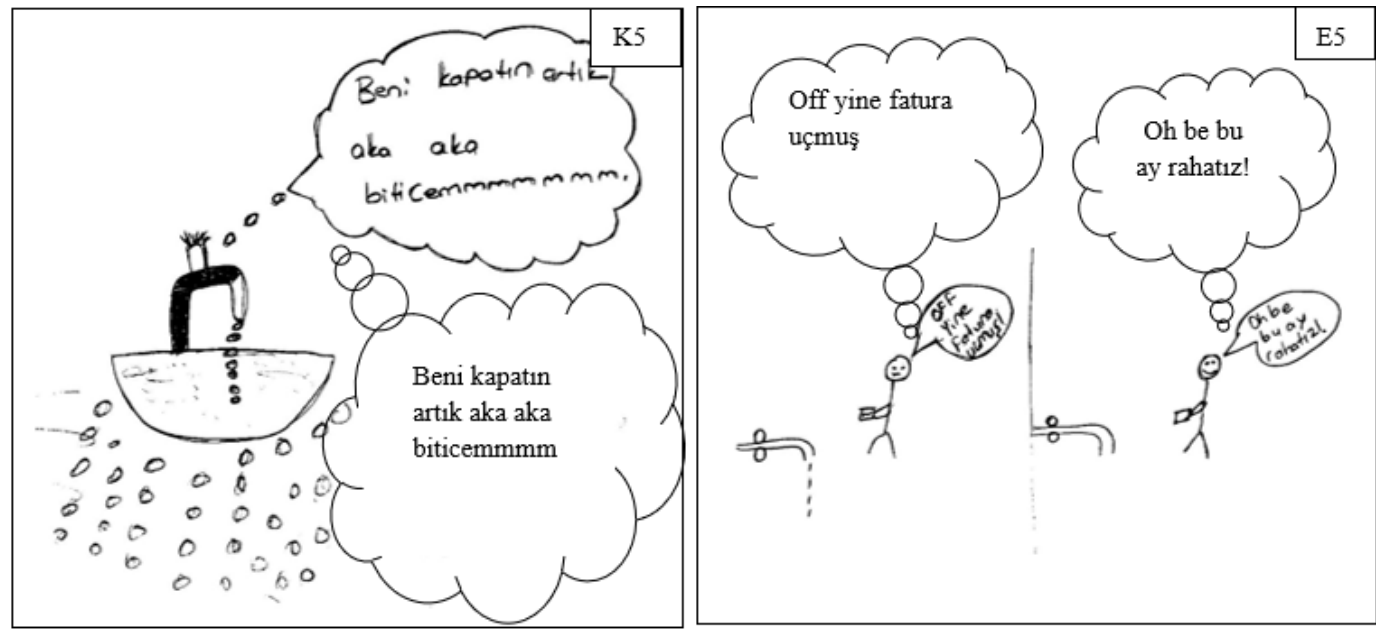

$\mathrm{Bu}$ kısımda öğrencilerden enerji dönüşümüne ilişkin bir bilim karikatürü çizmeleri istenmiştir. Bilim karikatürlerinde öğrencilerin çoğunun enerji dönüşümüne ilişkin çizim yapabildikleri gözlenmiştir. Öğrencilerin çizimlerinden elde edilen 
bulgulara göre k1z öğrencilerden $\mathrm{K} 10$ ve K6, erkek öğrencilerden ise E3 enerji dönüşümüne ilişkin çizmiş oldukları bilim karikatürlerinde ütü örneğini kullanarak elektrik enerjisinin 1S1 enerjisine dönüşmesini konu edinmişlerdir. Bir diğer enerji dönüşümü örneği olan rüzgâr enerjisinden elektrik elde etme yöntemine ise K7, E4, E6 ve E7'nin çizimlerinde rastlanmıştır. Kızlardan K1 erkeklerden E5 güneşten rüzgâr elde edilebileceğine dair çizimler yaparken, 3 k1z öğrenci $(K 2, K 8, K 9)$ güneşten elektrik elde edilebileceğine ilişkin çizimler yapmışlardır. K5 kodlu öğrenci çiziminde elektrik enerjisinin hareket enerjisine dönüşeceğini belirtirken, E1 kodlu öğrenci ise hareket enerjisinin elektrik enerjisine dönüşeceğine ilişkin çizim yapmıştır. K12 kodlu öğrenci yakıt olarak kullanılan kömürdeki kimyasal enerjinin 1s1 enerjisine dönüştüğünü konu alan bir karikatür çizerken, K11 kodlu öğrenci ateş böceklerinin yaydığ1 1şı̆̆1 çizmiş fakat çiziminde herhangi bir enerji dönüşümü örneğine yer vermemiştir.

E6 kodlu öğrenci Şekil 10'da yer alan çiziminde el çırpma sonucu oluşan hava akımının rüzgâr türbinlerinin dönmesine olumlu katkı sağlayacağını, rüzgâr enerjisinin elektrik enerjisine dönüşmesiyle daha fazla elektrik üretileceğini ve bu sayede elektrik fiyatlarının ucuzlayacağını anlatmıştır.

K4 kodlu öğrenci ise çiziminde sesin şiddeti sayesinde kırılan bir bardak örneğini enerji dönüşümüne örnek göstermiştir.

Şekil 10. E6 ve K4 Kodlu Öğrencilerin Çizimleri

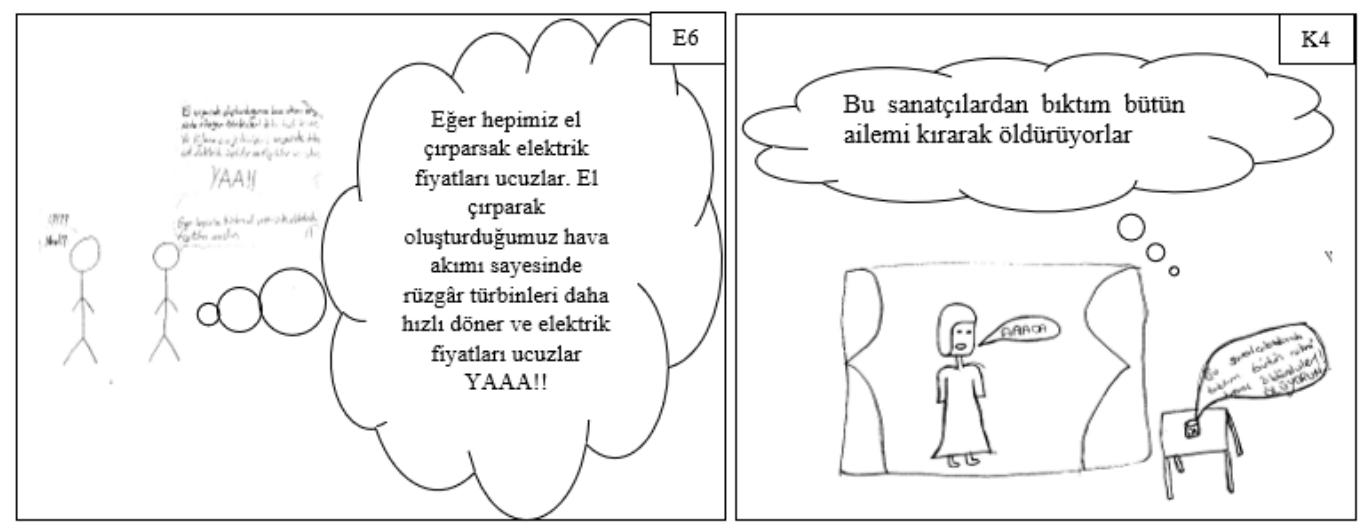

\section{Görüşmelerden Elde Edilen Bulgular}

4'ü kız 3'ü erkek olmak üzere toplam 7 öğrenci ile yapılan görüşmelerden elde edilen bulgular her başlık altında kız ve erkek öğrenciler açısından ayrı ayrı irdelenmiştir.

\section{Katılımcıların Enerji Kavramına İlişkin Algıları}

Katılımcıların enerji kavramına ilişkin algılarını anlamak amacıyla onlara "Enerji ne demektir? bu kavram sizin için ne ifade etmektedir?" sorusu yönetilmiştir. Öğrencilerin ifadelerinden elde edilen bulgulara göre 7 öğrenciye (4K ve 3E) enerjiyi nasıl tanımlarsınız sorusu yöneltilmiştir.

Sadece E6 kodlu öğrenci enerji için doğru tanım yapmış ve düşüncelerini "Enerji işte bir işi yapabilme gücüdür. Mesela potansiyel enerji kinetik enerjiye dönüşebiliyor. O zaman da o enerjiye sahip olan enerji hareket ediyor.” cümleleri ile açıklamıştır. E3 kodlu öğrenci ise düşüncelerini "Enerji bana göre günlük hayatta kullandığımız bir maddedir.” cümleleri ile ifade ederken E2: “...hareketlilik kazandıran 
bir şey gibi geliyor. Enerji olmazsa hayatın kötü olacă̆l, enerjisiz hayat düşünülemeyeceği ... insan vücudunda da enerji vardır, dışarda da. ” demiştir.

$\mathrm{K} 1 \mathrm{z}$ öğrencilerin tamamı ise (K1，K2，K8，K11) enerjinin tanımını yapamayacaklarını ama bazı enerji kaynaklarını örnek gösterebileceklerini ifade etmişlerdir. Örneğin K1 ve K8 sırasıyla şunları söylemişlerdir:

K1: "Enerji dediğimde isı enerjisi, elektrik enerjileri, enerjilerin dönüşümleri, potansiyel enerji, kinetik enerji onlar geliyor aklıma. Tam kelime anlamın bilmiyorum.” K8: "Enerjinin tam sözlük anlamını bilmiyorum mesela güneş enerjisi, ısı enerjisi, ışık enerjisi geliyor aklıma...” K2 ve K11 ise ifadelerinde direkt enerji türü örneklerine yer vermiştir. $K 2$ konu ile ilgili “...enerji mesela ısı enerjisi, ışılk enerjisi geliyor aklıma." açıklamasında bulunurken K11 "Enerji deyince ilk aklıma gelen şey güneş oluyor, rüzgâr oluyor. ” açıklamasını getirmiştir.

\section{Katılımcıların Enerji Sorunlarına İlişkin Algıları}

Katılımcıların tamamı enerji sorunlarının varlığı konusunda hem fikirdirler. Bununla birlikte katılımc1lardan (K2, K8, K11) bu sorunlar1 enerji tasarrufu yapılmaması olarak tanımlamışlardır. Katılımcılardan K2 düşüncesini “...çünkü çoğu insanlar bilgisizce davranıp tasarruf yapmıyor. Sözleriyle açıklarken, K8 ifadesini "mesela tasarruf yapılmaması benim için bir enerji sorunudur. Şeklinde yapmış, K11 ise enerji sorunlarına ilişkin benzer düşüncesini şu sözlerle belirtmiştir: "Tabi var enerji sorunları. Genelde ışık olarak hani fazla kullanıldı ̆̆ için..."

K1 enerji sorunlarını fosil yakıtların bilinçsizce kullanılması olarak şu sözlerle açıklarken; "Enerji sorunları fosil yakıtların daha çok kullanılmasıyla oluşan sorunlar, daha çok güneş enerjisinin kullanılması gerektiğini düşünüyorum.”, E3 için ise enerji sorunu mevcut durumda kullanılan enerji kaynaklarının bir gün tükenebilecek olmasıdır. E3: “...yani kaybetmek gibi bir şeydir. Insanlar çok kullanır, insan hayatı durabilir enerjisiz..., E6 enerji sorununu çevre kirliliği olarak algıladığını belirten ifadesinde şu sözlere yer verirken “...kaynakların kullanılması, hava kirliliği, çevre kirliliği...”; E2 kodlu öğrenci enerji sorununa ilişkin algısının diğer arkadaşlarından farklı olduğunu gösteren ifade ise şu şekilde beyan edilmiştir. E2: “...elektrik çarpması felan ...”

\section{Katılımcıların Enerji Tasarrufuna İlişkin Öğrenci Algıları}

Katılımcilara enerji tasarrufunun ne olduğu, gerekliliği ve bu tasarrufun ne şekilde yapılabileceği sorulmuş yapılan görüşmeler sonucunda öğrencilerin tamamının enerji sorunların varlığı sebebiyle enerji tasarrufu yapılması gerektiğini düşündükleri tespit edilmiştir.

Öğrencilerden K11 enerji tasarrufu konusunda insanların bilinçlendirilmesi gerektiğini şu sözlerle belirtirken, K11: “...bilgilendirilmeli insanlar bu konularda, çevrelere afişler filan asılmalı... kullandığım şeylere dikkat ederim mesela, hani suyu gereğinden fazla kullanmamaya çalışırım. Gereksiz yere lambaları ışıkları filan yakmam."

$\mathrm{K} 1, \mathrm{~K} 2, \mathrm{~K} 8$, E2, E3 ve E6 tasarrufun gerekli olduğunu ve nas1l yap1lmas1 gerektiğine ilişkin sahip oldukları düşünceleri E3, muslukları açık bırakmama "enerji tasarrufu etmek gereklidir. Mesela musluklart filan kapatıyorsun. K2 ve K8 gereksiz yanan lambaları kapatma olarak K2: "Enerji tasarrufu deyince mesela ışıkları çok fazla kullanıyorlar, o yüzden pek çok sorun çıkıyor.” K8: “enerji tasarrufunun gerekli 
olduğunu düşünüyorum. Mesela en basitinden kullanmadiğımız lambaları söndürebiliriz, sulart çok açmayabiliriz." gibi günlük hayattan örneklerle açıklamışlardır. Fosil yakıtların aşırı kullanımının enerji sorunlarına yol açtığını ifade eden $\mathrm{K} 1$ ise bu sorunlara çözüm yolu olarak enerji tasarrufunu fosil yakıtların daha az kullanılması olarak şu sözlerle ifade etmiştir: "Enerji tasarrufu yapılmalıdır. Her toplumda enerji sorunları olduğu için mesela ilk başta fosil yakıtların kullanılmaması gerekiyor."

\section{Katılımcıların Enerji Dönüşümüne İlişkin Algıları}

Katılımcılara enerji dönüşümünün ne olduğu, nasıl yapıldığı ve gerekliliği sorulmuştur.

Elde edilen bulgulara göre K1 ve K2 kodlu öğrencilere göre enerji dönüşümü elektrik enerjisinin 1S1 enerjisine dönüşümü şeklinde olmaktayken, K1:“...enerji dönüşümü elektrik enerjisinin isı enerjisine dönüşmesi gibi” K2: “...elektrik enerjisinin ısı enerjisine dönüşmesi. Elektrik yaparak ütünün ısınmasını düşündüm. ” K11'e göre 1s1 enerjisinin 1 şık enerjisine dönüşümü şeklinde gerçekleşmektedir "Işı̆̆̆ı ısıya dönüşmesi"

K8 konu ile ilgili düşüncelerini şu örneklerle açıklarken “...mesela enerjisinin ışı̆̆a dönüşmesi, elektrik enerjisinin ısıya dönüşmesi ya da hareket enerjisine dönüşmesi gibi. Mesela ampulü yaktı̆̆ımız zaman ışık veriyor bir süre sonra ampul ısınıyor çünkü ışık enerjisi ısı enerjisine dönüşüyor.” E6 enerji dönüşümünü "Mesela rüzgâr enerjisinde, hareket enerjisi rüzgâr enerjisine dönüşür. Elektrik enerjisi çalıştırılınca ışık enerjisine dönüştürülür, ışık enerjisi ısı enerjisine.” bu sözlerle açıklamıştır.

E2 kodlu öğrenci ise enerji dönüşümünü insan vücudunda ve dişarda olmak üzere iki çeşit olarak gerçekleşebileceğini “Enerji dönüşümü insan eliyle de olabilir dış etkilerle de olabilir. Mesela hareket ettiğimiz zaman vücudumuza isl enerjisi geliyor. Dış etkilere geldiğimiz zaman ise arabalar elektrikle güneş enerjisi panelinden ısı alıyor bunu hareket enerjisine çeviriyor." bu sözlerle ifade etmiştir.

Öğrencilere enerji dönüşümünün gerekli olup olmadığı sorulduğunda ise öğrencilerin tamamı enerji dönüşümünün gerekli olduğunu ifade etmişlerdir. Öğrencilerden E3, E6 ve K1 enerji dönüşümünün gerekliliğini bu sayede enerjiyi kullanabileceğimizi şu sözlerle ifade ederlerken E3: "Bence gerekli. Yoksa yani enerjiyi kullanamayız.” E6: "Enerji dönüşümü sayesinde her şey korunuyor işte yoksa her şey yok olabilirdi.” K1: "Enerji dönüşümü gereklidir. ...enerjiyi tek bir alanda kullanmak yerine birçok alanda kullanmak daha avantajlıdır.” K11 enerji dönüşümü sayesinde tasarruf yapabileceğimizi bu sebeple enerji dönüşümünün gerekli olduğunu şu ifadelerle belirtmiştir "Evet gereklidir. ... hani aslinda bu sayede tasarruf ta yapabiliriz." E2 ise enerji dönüşümüne ilişkin düşüncelerini "Bence enerji dönüşümü gerekli. Çünkü arabamıza benzin dolduruyoruz benzin her an bitebilir. Ama enerji dönüşümü olduğu zaman güneş enerjisini hareket enerjisine çevirebiliriz. " sözleriyle ifade etmiştir.

\section{Katılımcıların Yenilenebilir Enerji Kaynaklarına İlişsin Algıları}

Katılımcılara yenilenebilir enerji kaynaklarının neler olduğu ve bu kaynakların neden yenilenebilir olduğu sorulmuştur. Öğrencilerin ifadelerinden oluşturulan kodlara göre K1, K8 ve E6 için yenilenebilir enerji kaynakları güneş ve rüzgârdır. Öğrencilerin 
vermiş oldukları ifadeler K1 tarafından "Güneş, rüzgâr bunlar.” şeklinde, K8 ve E6 da tarafından da K8: "Mesela güneş enerjisi, rüzgâr enerjisi gibi...” E6: “Güneş enerji kaynăgl... Rüzgâr var" gibi benzer şekilde ifade edilmiştir. E2 kodlu öğrenci ise yenilenebilir enerji kaynağı olarak "Mesela su gücüyle değirmen çalışması.” sözlerini kullanmıştır.

Öğrencilere verdiği örneklerdeki kaynaklara neden yenilenebilir enerji kaynağ1 denildiği sorulduğunda ise kızların tamamı bu kaynakların tükenmeyeceğini tekrardan kullanılabileceğini şu sözlerle ifade etmişlerdir. K11: "Hani tekrardan kullanılabildiği için.” K8: "Adı üstünde yenilenebilir. Hani dönüştürülebilir olduğu için devamının gelebildiği için tükenmediği için yenilenebilir.” K2: “Güneş mesela tükenmiyor.” K1: “...fosil yakıtlar mesela belli şey ürettikten sonra tekrar üretmek gerekiyor. Ama güneş belli saatler boyunca sürekli havada veya rüzgâr yaşamımı boyunca sürekli vardır.”

E2 kodlu öğrenci bu durumu kaynakların uzun ömürlü olmasına şu sözlerle bağlarken “...benzin mesela iki üç günde doldurursun ama yenilenebilir enerji kaynakları biraz maliyetli de olsa uzun ömürlü...” E6 ise bu kaynakların çevreye zarar vermediklerini, bu yüzden yenilenebilir enerji kaynağı olarak adlandırıldıklarını "Çünkü hem çevreye zarar vermiyor. Hem de güneş tüm enerjilerin kaynă̆ ..." bu şekilde ifade etmiştir.

\section{Katılımcıların Yenilenebilir Enerji Kaynakları Kullanımının Çevreye Olan Etkilerine İlişkin Algıları}

Katılımcılara yenilenebilir enerji kaynakları kullanımının çevreye etkilerinin neler olduğu sorulmuştur.

Elde edilen bulgulara göre öğrencilerin tamamı yenilenebilir enerji kaynakları kullanımının çevreye olumlu etkileri olacağını ifade etmişlerdir. Öğrencilerden K8 yenilenebilir enerji kaynaklarının ekonomik olduğunu "...hani doğadan olduğu için bütçeye zararı olmuyor. Devlete de pek zararı olmuyor.” sözleriyle belirtirken, K1 ve E2 bu kaynakların çevreyi kirletmediğini K1 “...fosil yakıtlar asit yağmurlarına sebep oluyor. Bu yüzden yenilenebilir enerji kaynaklarının daha să̆llklı olabileceğini düşünüyorum.”, E2 “...güneşten aldı̆̆ımız enerjiyi direk arabaya veriyoruz ve çevreye hiçbir zararı olmuyor... asit yağmurlarının olmadığını gözlemliyoruz." K2 ise bu kaynakların bitkilere ve insanlar olumlu etkileri olduğunu “... kömür doğalgaz yerine güneş enerjisi kullanılıyor mesela bu gayet olumlu... mesela güneş çiçeklere filanda büyük katkıları oluyor." bu sözlerle ifade etmişlerdir:

Öte yandan K11 yenilenebilir enerji kaynaklarından biri olan güneşin zararlı 1şınlarının olduğunu kurulacak güneş panelleri sayesinde bu 1şınlardan kurtulma imkânı olduğunu şu sözlerle ifade etmiştir “...olumlu olacağını düşünüyorum aslında çünkü güneş panelleri zararlı ışılnları bir taraftan aldığı için...”

Ayrıca öğrencilerden E3 ve E6 yenilenebilir enerji kaynaklarının çevreye olumlu etkileri olduğunu belirtmekle beraber olumsuz etkilerinin olabileceğini de ifadelerine eklemişlerdir. E3: "iyi etkisi de olur kötü etkisi de. Mesela elektrik prizleri açık kalınca bir çocuk çarptığı zaman olumsuz. Olumlu da yani ışılklar açılmaz, market işlemez. Ya da ders işlenmez..." E6: "İşte bir kere karbon monoksit, karbondioksit felan zehirli gazlar oluşmaz... asit yağmuru olmaz, daha güvenli enerji kaynă̆ıdır, daha az kirlenir çevre. Ondan sonra olumsuz olarak ta mesela gürültü yapabilir, görüntü kirliliği..." 


\section{Katılımcıların Yenilenemez Enerji Kaynaklarına İlişkin Algıları}

Katılımcılara yenilenemez enerji kaynaklarının neler olduğu ve bu kaynakların neden yenilenemez enerji kaynakları olarak ifade edildikleri sorulmuştur.

Elde edilen bulgulara göre; öğrenciler yenilenemez enerji kaynaklarına ilişkin fosil yakıtlar, K1: "Fosil yakıtlar olduğunu düşünüyorum.” Kömür K8: “...mesela kömür gibi...", doğalgaz, odun, petrol E3: "Petrol.", nükleer enerji E6: "Mesela fosil yakıtlar. Ondan sonra nükleer enerji." örneklerini vermişlerdir.

Öğrencilere, verdiği örneklerdeki kaynaklara neden yenilenemez enerji kaynağ1 denildiği sorulduğunda ise kızlardan K1 ve K11 kaynakların çevreye zarar verdiğini, tükeneceğini tekrardan kullanılamayacağını şu sözlerle ifade ederken "Bir kere çevreye zarar veriyor diğeri de tükettikten sonra geri dönmüyor...” K11: "çevreye olumsuz etkisi olduğu için, hani tükendiği için.” $\mathrm{K} 2$ ve K8 de benzer cümlelerle şu açıklamaları yapmışlardır K2: "Çünkü bunlar tüketiyoruz ve bitiyor..." K8: "Adl üstünde yenilenemez, dönüş̧ürülemez, yani sonu belli tükenebilir. Kömür çevreye de etkileri zaten olumsuz"

Erkeklerden E3 ve E6 kodlu öğrenciler kaynakların tükenebileceğini, bu yüzden yenilenemez enerji kaynakları olarak adlandırıldığını ifade ederlerken E3: "Petrol kullandı̆̆ımızda geri dönmüyor uçuyor." E6: “çünkü maddeye bağlllar ve dünyada sinırlı olarak bulunuyorlar yeniden oluşmaları da çok zaman altyor.” E2 kodlu öğrenci bu durumu yenilenemez enerji kaynaklarının çevreye ve insanlara zarar verdiğini bu yüzden yenilenemez olarak adlandırıldığını şu şekilde belirtirken "İnsan săglı̆̆ına zarar verebilir. Dişarda çevreye ağaçlara zarar verebilir." Tükenme ve yenilenememe gibi özelliklerine vurgu yapmamıştır.

\section{Katılımcıların Yenilenemez Enerji Kaynakları Kullanımının Çevreye Olan Etkilerine İlişkin Algıları}

$\mathrm{Bu}$ kısımda öğrencilere yenilenemez enerji kaynakları kullanımının çevreye etkilerinin neler olduğu sorulmuştur. Yenilenemez enerji kaynakları kullanımının çevreye etkilerine ilişkin kız ve erkek öğrencilerin tamamı bu kaynakların kullanımının çevreyi olumsuz etkilediklerini belirtmişlerdir. Öğrencilerden bu olumsuzluğu çevre kirliliği, hava kirliliği, insan sağlığına zarar gibi ifadeler kullanarak açıklamaya çalışmışlardır.

Örneğin K1 ve K8'in konu ile ilgili düşünceleri sırasıyla "Olumsuz, zararl olur. Ilk başta asit yăgmurları hava kirliliğine sebep olur, çevre kirliliği yani."; "Mesela bacadan çıkan zararlı şeyler çevreye zarar veriyor, ozon tabakasının delinmesinde çevreye etkili olduğu için zararlı olduğunu düşünüyorum." Şeklindedir.

K2 ve E2 kodlu öğrenciler de diğer arkadaşları gibi yenilenemez enerji kaynakları kullanımının çevreye olumsuz etkileri olabileceğini belirtmekle beraber insan sağlı̆̆ına zarar verebileceğini temel alan K2: "Olumsuz. Insanların ölümüne kadar gidebiliyor, mesela kömürde dediğim gibi, doğalgaz patlamalarından dolayı insanlar ölebiliyor" E2: "İnsan sağlığına zararı çok yüksek. Mesela toprak kaybı, toprak kirli havayı tutar toprak kayınca kirli hava insan sağlığına zarar verir.” bu ifadeleri kullanmışlardır.

Öğrencilerden K11 bu kaynakların patlamalarının çevreye zarar verebileceğini "Patlama anında çevreye büyük etkisi olur." sözleriyle ifade ederken E6 benzer 
düşüncelerini "Çok büyük etkileri olur çünkü çok güçlü kaynaklar, en ufak bir dikkatsizlikte çok büyük zarar verebilir. Atmosferi kirletirler.” şeklinde açıklamıştır.

E3 kodlu öğrenci ise diğer arkadaşları gibi yenilenemez enerji kaynaklarının olumsuz etkilerin olduğunu belirtmekle beraber olumlu etkileri de olduğunu, yenilenemez enerji kaynaklarından biri olan petrol sayesinde arabaların çalıştığını "Olumlu veya olumsuz etkileri olabilir. Olumlu olarak bir arabaya petrolü koyduğumuz zamana gidecĕgimiz yere ulaşabiliyoruz, ama olumsuz yönde o petrolü kullandiğımızda havayı kirletiyor. Havayı kirlettiğinde de bize de zarar verir." şeklinde ifade etmiştir.

\section{Sonuç ve Tartıșma}

Sekizinci sınıf öğrencilerinin enerji sorunları ve yenilenebilir enerji kaynaklarına ilişkin algılarının araştırıldığı bu çalışmada ilgi çekici sonuçlara ulaşılmıştır.

Enerji, alan yazında iş yapabilme yeteneği olarak tanımlanmış ve eğitim-öğretim programlarında bu tanımla yerini almıştır. Yedi öğrenciyle (4K, 3E) gerçekleştirilen görüşmelerde öğrencilere enerji kavramına ilişkin algılarının neler olduğu sorulmuştur. Verilen cevaplar incelendiğinde E6 kodlu öğrenci hariç diğer öğrencilerin enerjiye ilişkin yeterli tanım yapamadıkları ancak çeşitli enerji kaynaklarını örnek göstererek enerji kavramına ilişkin açıklamalar geliştirmeye çalıştıkları görülmüştür. Öğrencilerin enerji kaynaklarını örnek göstermeleri enerji kavramını somutlaştırarak ifade etmeye çalıştıklarını dolayısıyla öğrencilerin altısının enerji kavramına ilişkin yeterli algıya sahip olmadıklarını göstermiştir. Bu durum alanyazında yer alan Töman ve OdabaşıÇimer (2011) tarafından yapılan çalışmalarda enerjinin farklı öğrenim seviyelerinde yer alan öğrencilerin çoğu tarafından tam olarak bilinmediği sonucuyla benzerlik göstermektedir. Ayrıca E2 kodlu öğrencinin enerjiyi "hareket" olarak tanımlamaya çalışması Çökelez, Yürümezoğlu ve Ayaz (2009), sekizinci sınıf öğrencilerinin \%17.5'inin enerjiyi hareket olarak tanımladıkları sonucuyla da benzerlik gösterdiği görülmektedir. Öğrencilerin enerjiye ilişkin tanım yapamamaları alanyazında enerji kavramının soyut olması bu yüzden zihinlerinde yapılandırmalarında zorluk çekmeleri yönünde açıklanmaya çalışılmıştır. Fakat alanyazında yer alan çalışmalar incelendiğinde enerjinin sadece ilkokul öğrencileri tarafından değil Piaget'nin öğrenme kuramına göre soyut işlemler döneminde olmaları beklenen 11 yaş sonrası lise, üniversite gibi farklı seviyelerde öğrenim görmekte olan öğrencilerin çoğu tarafından da bilinmediği görülmüştür (Töman \& Odabaşı-Çimer 2011). Bu açıdan bakıldığında öğrencilerin enerji kavramına ilişkin yeterli algıya sahip olamamalarının sebebi enerji kavramının soyut olmasından ziyade bu kavramın öğretilmesi noktasında verilen eğitimin yetersiz olduğu düşünülmektedir.

Öğrencilere enerji sorunlarına ilişkin düşünceleri sorulduğunda; tamamının enerji sorunlarının varlığını kabul ettiği, bu sorunların kaynağı sorulduğunda ise dört kız öğrencinin tamamı üç erkek öğrenciden de birinin enerji sorunlarını enerji kaynaklarının fazla kullanılmasına bağladığı belirlenmiştir. Bu sonuç Çökelez ve arkadaşlarının (2009) çalışmalarından elde ettikleri sonuç ile benzerlik göstermektedir. Sadece bir erkek öğrenci enerji sorunlarını kaynakların fazla kullanılması ve çevre kirliliğine yol açması şeklinde tanımlarken bir erkek öğrenci enerji sorununu elektrik çarpması olarak ifade etmiştir bu durum öğrencinin, enerjinin kullanılması noktasında alınan tedbirlerin yetersiz olduğunu bu yönüyle enerjinin kullanımının insan hayatı için tehlike arz ettiğini düşündüğünü göstermektedir. Görüşme gerçekleştirilen yedi öğrenciden sadece birinin 
enerji sorunlarını doğru tanımladığı göz önüne alındığında öğrencilerin enerji sorunlarına ilişkin algılarının yeterli düzeyde olmadığı bir öğrencinin ise enerji sorunlarına ilişkin yanlış algıya sahip olduğu görülmüştür.

$\mathrm{Bu}$ durum öğrencilerin enerji sorunlarına ilişkin farkındalık düzeylerinin düşük olduğunu göstermektedir. Enerji sorunlarına ilişkin farkındalık düzeyi düşük, bu konuda yeterli algıya sahip olmayan öğrencilerin ilerde, enerji kaynaklarının kullanımına, bu kaynakların korunmasına ve alternatif enerji kaynaklarının tercih edilmesine ilişkin bilinçli birer bireyler olamayacaklarını dolayısıyla çevreyi koruma ve çevre sorunlarına çözüm üretme noktasında duyarsız davranabileceklerini düşündürmektedir. Oysa çevreye karşı olumlu tutuma sahip olmak ve onu koruma noktasında duyarlı davranışlar sergilemek branş farkı gözetmeksizin eğitimin tüm disiplinlerinde bireye kazandırılması gereken oldukça önemli bir özellik olarak yer almaktadır.

Yenilenebilir enerji kaynakları farklı türlerde olmasına rağmen öğrencilerin bu kaynaklara ilişkin yapmış oldukları çizimlerde güneş, rüzgâr ve sudan başka kaynaklara rastlanmamıştır. $\mathrm{Bu}$ sonuç Kılıçarslan, Peker ve Gün'ün (2011) ilköğretim öğrencileriyle gerçekleştirdikleri çalışmanın sonucuyla paralellik göstermektedir. Ayrıca yedi öğrenciyle gerçekleştirilen görüşmeler de göstermektedir ki; öğrencilerin yenilenebilir enerji kaynaklarına ilişkin algıları güneş, rüzgâr ve suyla sınırlıdır. Öğrencilerin güneş, rüzgâr, dalga, hidrojen, hidroelektrik, biyokütle, jeotermal enerji gibi birçok yenilenebilir enerji kaynağından sadece güneş ve rüzgâra yer vermiş olmaları bu konuda algı düzeylerinin düşük olduğunu göstermektedir. Araştırmadan elde edilen bu sonuç, Akçöltekin ve Doğan'ın (2013) sınıf öğretmenleriyle, Bilen, Özel ve Sürücü’nün (2013) öğretmen adaylarıyla, Tobin ve arkadaşlarının (2012) ilköğretim ve ortaöğretim öğretmenleriyle, Karabulut ve arkadaşlarının (2011) üniversite öğrencileriyle ve Yılmaz ve arkadaşlarının (2010) ise halkla yaptıkları araştırmalardan elde ettikleri, yenilenebilir enerji kaynakları hakkında insanların yeterli bilgiye sahip olmadıkları yönündeki sonuçlarla benzerlik göstermektedir. Ayrıca bu sonuç Tanrıverdi (2009), Bilen ve arkadaşları (2013) çalışmalarında ifade edildiği gibi, yenilenebilir enerji kaynaklarına ilişkin programlarda yer alan öğrenci kazanımlarının çoğunlukla güneş ve jeotermal enerji üzerinde yoğunlaşmış olduğu, ancak diğer yenilenebilir enerji kaynakları olan rüzgâr, biyoenerji, su ve gelgit enerjisi ile ilgili kazanımlara yer verilmediği görüşlerini de destekler niteliktedir.

Öğrencilerin yenilenebilir enerji kaynakları kullanımının çevreye olan etkilerine ilişkin yapmış oldukları çizimler incelendiğinde 12 kı öğrencinin 8'i, 8 erkek öğrencinin 6'sı yenilenebilir enerji kaynaklarının kullanımının çevreye olumlu etkileri olduğunu belirtmiştir. $\mathrm{Bu}$ durum katılımcıların çevre sorunlarının çözümü için yenilenebilir enerji kaynaklarının kullanımını önemsedikleri şeklinde yorumlanabilir. Ancak 3 kız ve 1 erkek öğrenci olaya farklı bir bakış açısıyla yaklaşarak, yenilenebilir enerji kaynaklarından biri olan rüzgârın ağaçlara zarar verdiğini, atıkları sürüklediğini, güneşin ise zararlı 1şınları olduğunu, dolayısıyla bu kaynakların çevreye olumsuz etkileri olduğunu belirtmişlerdir. Sonuçlar aynı zamanda kız ve erkek öğrencilerin yenilenebilir enerjiye yönelik tutumları arasında ciddi farklılıkların bulunmadığını göstermiştir. Yenice ve Alpak Tunç (2018) tarafından fen bilgisi öğretmen adaylarının yenilenebilir enerjiye yönelik tutumlarını belirlemek için gerçekleştirilen bir araştırmada ise katılımcıların yenilenebilir enerji kaynaklarına yönelik tutumlarının olumlu düzeye yakın olduğu belirlenmiştir. Literatürde yer alan farklı çalışmalarda da bu bulguyu 
destekleyen sonuçlar ortaya çıkarılmıştır (Kaldellis, Kapsali, \& Katsanou, 2012; Tiftikçi, 2014).

Öğrenciler yenilenemez enerji kaynaklarına ilişkin yapmış oldukları çizimlerde öncelikli olarak kömür, petrol ve benzine yer vermişlerdir. Ancak iki kız öğrenci diğer öğrencilerden farklı olarak çizimlerinde nükleer santral ve doğalgaza yer vermişlerdir. İncelenen çizimler sonucunda öğrencilerin 13'ünün yenilenemez enerji kaynaklarına ilişkin algılarının kömür veya petrolden ibaret olduğu gözlenmiştir. $\mathrm{Bu}$ durumun kömürün ülkemizde toplam birincil enerji kaynakları üretiminde $\% 55.5$ gibi oldukça büyük bir oran ile ilk sırada yer almasından, dolayısıyla öğrencilerin günlük hayatta daha çok karşılaşmalarından kaynaklandığı düşünülmektedir (Yılmaz, 2010). Çalışmadan elde edilen bu sonuç Töman ve Odabaş1-Çimer'in (2013) çalışmalarından elde edilen sonuçla benzerlik göstermektedir. Ayrıca benzinin petrol eldesi bir ürün olması, yenilenemez enerji kaynaklarına ilişkin çizimlerinde benzin örneğine yer veren öğrencilerin petrol ve türevleri arasındaki ilişkiyi tam olarak algılayamadıklarını da göstermektedir.

\section{Öneriler}

Araştırmadan elde edilen sonuçlar doğrultusunda şu önerilerde bulunulabilir:

Öğrencilerin enerji ile ilgili algılarının yetersiz olması bu konunun soyut olmasından kaynaklanabileceği için öğrencilere verilecek eğitimin küçük yaşlarda öğrenciler için somutlaştırılması ileri dönemlerde oluşabilecek kavram yanılgılarının önüne geçebilir. Öğrencilerin eğitimlerinin konuyla ilgili sorumluluk almalarını sağlayan projeler, uygulamalar ile desteklenmesi yeterli algıya sahip enerji konusunda olmaları bilinçli bireyler olarak yetişmeleri noktasında faydalı olacağı düşünülmektedir.

Öğrencilerin enerji sorunları varlığını kabul etmelerine rağmen bu sorunlara ilişkin yeterli açıklama getirememeleri bu durumun, enerji sorunlarına ilişkin verilen eğitimin yetersiz, yüzeysel ve ezbere yönelik olduğunu ve dolayısıyla konunun yeterince özümsenmediğini gösterebilir. Bu noktada verilecek eğitimin öğrencilerin yaparak yaşayarak öğrenmelerine imkân sağlayan, öğrenci merkezli eğitim olmasıyla giderilebileceği düşünülmektedir.

Öğrencilerin yenilenebilir ve yenilenemez enerji kaynaklarına ilişkin az sayıda örnek ürettikleri ve bu örneklerin genellikle günlük hayatta karşılaştıkları enerji kaynakları olduğu görülmektedir. Bu durum öğrencilere verilecek eğitimin günlük hayatla ilişkilendirilmesi gerekliliğini de gözler önüne sermiştir.

Ayrıca çalışma sonucunda elde edilen bulgular incelendiğinde öğrencilerin büyük çoğunluğunun algılarının sınırlı düzeyde olmasının yanı sıra bazı öğrencilerin ise yanlış algılara sahip olduğu görülmektedir. Öğrencilerin bu konulara ilişkin yeterli düzeyde algıya sahip olmaları noktasında öncelikle sahip oldukları bilimsel olmayan bilgilerin belirlenmesi ve düzeltilmesi amacıyla da verilecek eğitimin oldukça önemli olduğu düşünülmektedir. 


\section{Summary}

Purpose and Significance: The environment can be defined as the environment in which people and all living things on earth interact with each other (Seçgin, Yalvaç, \& Çetin, 2010). Therefore, although the environment is very important for the living, environmental problems are increasing rapidly. According to the OECD environmental report, unconscious energy consumption is at the beginning of environmental problems (OECD, 2008). The end result of many scientific researches on energy problems suggests the use of renewable energy sources as an alternative to fossil fuels. These sources cause very little environmental pollution.

For this reason, it is important for the environment that individuals use renewable energy sources. In this context, environmental problems and search for solutions to these problems have been the subject of many educational researches. Although research on environmental problems is often found in studies conducted by individuals at almost every level of education, there are only a limited number of studies in which the perceptions of middle school students regarding energy problems and renewable energies, one of the basic elements of environmental awareness, are explored (Kilıçaslan, Peker, \& Gün, 2011). However, the perceptions of secondary school students about energy problems and renewable energy sources, which have great importance in creating environmental awareness, are very important at the point where they can influence their environmental attitudes, environmental awareness and sensitivities.

Cartoons are one of the best tools for revealing perceptions of a subject (Keogh \& Naylor, 1999). Scientific cartoons are described by Srivastava as cartoons which are subject matter science (Srivastava, 2011). It is also known that science caricatures carry universal language qualities because they are visual as well as the advantages of providing effective communication and facilitating the understanding of complex scientific expressions (Srivastava, 2011). With humor in cartoon, a powerful visual tool, people have the opportunity to express their emotions and thoughts as they deal with criticism of events, situations, or people, including the element of humor (Ersoy \& Türkkan, 2010).

In this study, students' science cartoons were utilized to draw out the perceptions of energy issues and renewable energy sources.

Method: In this study, which aims to reveal the perceptions of eighth grade students about energy problems and renewable energy sources by science cartoons, phenomenology is used. Participants are 20 students totally, who are studying in a secondary school in Kayseri in the second semester of the academic year of 2014-2015, determined by criterion sampling, and 12 female and 8 male at the eighth grade level. Process of the study lasted 4 weeks. Science cartoons drawn by the students and semistructured interviews were used as data collection tools in the study. The data were analyzed by content analysis.

Results: In this research students have drawn science cartoons on energy problems, renewable and non-renewable energy sources, environmental effects of the use of these 
resources and energy saving. Findings from these drawings show that the vast majority of students think that renewable energy sources are sun and wind.

Students stated that the use of renewable energy sources in caricatures they have drawn may have positive or negative effects on the environment. According to the findings of participants' science cartoons drawn on non-renewable energy sources, the students mainly used coal and petroleum samples.

Participants' perceptions about the environmental impact of the use of non-renewable energy sources indicated that the use of these resources was necessary, with no gender differences in the fact that these sources had a negative impact on the environment, with 2 students.

When participants' perceptions of energy saving were examined, it was seen that girls and boys took the place of electricity saving as the first place. One male student was drawing energy saving conference. Drawing from the fact that a speaker is talking about the necessity of saving energy for the world, the student described how the speaker of the sun and birds participated in the idea and how humans were insensitive to this issue by giving the person who spoke at the conference "yuuh".

In the findings of the students drawn from the caricatures drawn about the energy conversion, the conversion of electricity energy to heat energy is a way of obtaining electricity from wind energy, from which electricity can be obtained from the sun. In a male student's drawing, the resultant clutter of air flow will contribute positively to the turning of wind turbines and that more electricity will be generated by turning the wind energy into electrical energy and the electricity prices will be cheaper.

In the interviews carried out parallel to the subjects performed in the cartoons, it was determined that the expressions support the findings obtained from the drawings.

Discussion and Conclusions: In interviews with seven students, it was seen that students could not define energy but tried to develop explanations about energy concept by exemplifying various energy sources. This situation has shown that students do not have enough perception about the concept of energy.

When students are asked about their thoughts on energy problems; all have acknowledged the existence of energy problems, many of whom point to the source of these problems as overuse of energy resources. This situation resembles the result of the work done by Töman and Odabaşı-Çimer (2011).

Although the renewable energy sources are in different genres, there are no sources other than sun, wind and water in the drawings of the students. This result obtained from the research was obtained by the students of Akçöltekin and Doğan (2013), primary school teachers and secondary school teachers of Bilbin, Özel Yilmaz and his colleagues (2010) show similar results to the results of research done by the public about the fact that people do not have enough knowledge about renewable energy sources.

As a result of the drawings examined, it was observed that 13 of the students' perceptions of non-renewable energy sources consisted of coal or oil. This is thought to be due to the fact that the primary energy sources in our country are in the first place with $55.5 \%$ of total production, thus students are encountered more in daily life 
(Y1lmaz, 2010). This result obtained without working is similar to the results obtained from the work of Töman and Odabaş1-Çimer (2013). 


\section{Kaynakça}

Akçöltekin, A., \& Doğan, S. (2013). Sınıf öğretmenlerinin yenilenebilir enerji hakkındaki tutumlarının belirlenmesi. International Journal of Social Science, 6(1), 143-153.

Akınoğlu, O., \& Sarı, A. (2009). İlköğretim programlarında çevre eğitimi. M.Ü. Atatürk Eğitim Fakültesi Ĕ̆itim Bilimleri Dergisi, 2(30), 5-29.

Aksan, Z., \& Çelikler, D. (2013). İlköğretim öğretmen adaylarının küresel ısınma konusundaki görüşleri. Eskişehir Osmangazi Üniversitesi Sosyal Bilimler Dergisi, 14(1), 49-67.

Aydın, M., \& Ürey, M. (2014). İlköğretim fen ve teknoloji dersi programında yer alan çevre konularına yönelik bir program analizi. Kafkas Üniversitesi, E - Kafkas Ĕ̈itim Araştırmaları Dergisi, 1(2), 37-50.

Berg, B. L. (2001). Qualitative research methods for the social science (fourth edition). Boston: Allyn \& Bacon.

Bilen, K., Özel, M., \& Sürücü, A. (2013). Fen bilgisi öğretmen adaylarının yenilenebilir enerjiye yönelik tutumları. Dumlupınar Üniversitesi Sosyal Bilimler Dergisi, 36, 101-112.

Bozdoğan, A. E., \& Yalçın, N. (2006). Bilim merkezlerinin ilköğretim öğrencilerinin fene karşı ilgi düzeylerinin değişmesine ve akademik başarılarına etkisi: enerji park1. Ege Ĕ̈itim Dergisi, 2(7), 95-114.

Creswell, J. W. (2008). Educational research planning, conducting and evaluating quantitative and qualitative research. International Pearson Merril Prentice Hall.

Çökelez, A., Yürümezoğlu K., \& Ayaz, S. (2009). İlköğretim ikinci kademe öğrencilerinin enerji ve enerji ile ilgili kavramları algılamaları. Necatibey Eğitim Fakültesi Elektronik Fen ve Matematik Eğitimi Dergisi, 3(2), 52-79.

Ersoy, A. F., \& Türkkan, B. (2010). İlköğretim öğrencilerinin çizdikleri karikatürlerle yansittıkları sosyal ve çevresel sorunların incelenmesi. Education and Science, 35(156), 96-109.

Güney, E. (2004). Türkiye çevre sorunları. Ankara: Nobel Yayın Dağıtım.

Kaldellis, J. K., Kapsali, M., \& Katsanou, E. (2012). Renewable energy applications in Greece. What is the public attitude?. Energy Policy, 42, 37-48.

Karabulut, A., Gedik, E., Keçebaş, A., \& Alkan, M. A. (2011). An investigation on renewable energy education at the university level in turkey. Renewable Energy, 36(4), 1293-1297.

Keogh, B., \& Naylor, S. (1997). Starting points for science. Sandbach: Millgate House.

Kılıçaslan, M., Peker, E.A., \& Gün, F. (2011). Yenilenebilir enerji kaynaklarının çevreye olan katkısına ilişkin ilköğretim öğrenci görüşleri: Samsun İli örneği. Samsun Sempozyumu'nda sunuldu.

OECD (2008). Çevresel performans incelemeleri Türkiye. http://www.oecd.org/environment/country-reviews/42198785.pdf $\quad$ (Erişim tarihi:17.11.2016)

Öztürk, M. (2014). Coğrafya ĕgitiminde araştırma (2.Baskı). Pegem Akademi: Ankara. 
Seçgin, F., Yalvaç, G., \& Çetin, T. (2010). İlköğretim 8. sınıf öğrencilerinin karikatürler aracılığıyla çevre sorunlarına ilişkin algıları. In Proceedings of International Conference On New Trends in Education and Their Implications, 391-398.

Srivastava, P. K. (2011). Scienstoons and scientoonics: A novel way of learning and enjoying science. Retrieved from http://www.scientoon.com/ on 05 March 2018.

Tanrıverdi, B. (2009). Sürdürülebilir çevre eğitimi açısından ilköğretim programlarının değerlendirilmesi. Eğitim ve Bilim, 34(151), 91-103.

Tatalovic, M. (2009). Science comics as tools for science education and communication: A brief, exploratory study. Jcom, 8(4), A02.

Tiftikçi, H. İ. (2014). Farklı bölümlerde ögrenim görmekte olan son sınıf üniversite ögrencilerinin yenilenebilir enerji kaynakları hakkındaki farkındalıkları (Yaymlanmamış Yüksek Lisans Tezi). Gazi Üniversitesi, Eğitim Bilimleri Enstitüsü, Ankara.

Tobin, R. G., Crissman, S., Doubler, S., Gallagher, H., Goldstein, G., Lacy, S., Rogers, G. B., Schwartz, J., \& Wagoner, P. (2012). Teaching teachers about energy: Lessons from an inquiry-based workshop for K-8 teachers. Journal of science Education and Technology, 21(5), 631-639.

Van Manen, M. (1990). Researching lived experience. New York: State University of New York Press.

WWF, (2011). Yenilenebilir enerji geleceği ve Türkiye. WWF Raporu. http://awsassets.wwftr.panda.org/downloads/wwftr_yenilenebilirenerjigelecegivetur kiye.pdf.

Yıldırım, A., \& Şimşek, H. (2011). Sosyal bilimlerde nitel araştırma yöntemleri. (8. Bask1). Ankara: Seçkin Yayıncılık.

Yılmaz, V., Çelik, H., \& Arslan, T. (2010). Enerji çeşitleri ve geri dönüşüme karş1 tutumların çevresel davranışa etkisi. Fırat Üniversitesi Sosyal Bilimler Dergisi, 20(2), 323-342.

This is an Open Access article distributed under the terms of the Creative CommonsAttributionNonCommercial-ShareAlike 4.0 International (CC BY-NC-SA 4.0). For further information, you can refer to https://creativecommons.org/licenses/by-nc-sa/4.0/ 